\title{
Through the eyes of science and art: a fourteenth-century winter breviary from Alcobaça scriptorium
}

\author{
Catarina Fernandes Barreira ${ }^{a}$, Maria João Melo ${ }^{a, b}$, Rita Araújo ${ }^{a, b}$ and \\ Conceição Casanova ${ }^{a, b}$
}

${ }^{a}$ IEM Instituto de Estudos Medievais, FCSH, Universidade NOVA de Lisboa, Lisbon, Portugal; ${ }^{b}$ Department of Conservation and Restoration and REQUIMTE, LAQV, Faculty of Sciences and Technology, Universidade NOVA de Lisboa, 2829-516 Monte da Caparica, Portugal

\section{ABSTRACT}

The collection of manuscripts from the monastery of Alcobaça is one of the most important in the Cistercian world. The scriptorium was active from the end of the twelfth to the sixteenth century, and during the end of the thirteenth and the beginning of the fourteenth centuries, transformations both in the materials used for colour and in style, namely historiated and filigreed initials, occurred. In this paper, through the study of a little-known manuscript, the winter Breviary Alc. 54, we will analyse these changes through a study of the pigments applied but also through the liturgy, which enables us to date the manuscript in the Alcobaça scriptorium with an original corpus from the earlier fourteenth century and two additions that were introduced during the second half of the fifteenth century. We argue that these transformations in style, materials and technique were catalysed by the entrance of "university" manuscripts into the abbey. In short, this research shows that the scriptorium was receptive to new ideas, which were absorbed and adapted to its own context. This manuscript provides examples of this: the use of silver in the illuminations, the updating of the palette, the French influence in the historiated initials, and the pen-flourished initials. While these changes were occurring, other Cistercian liturgical traditions and colour application technology stayed in use.

\section{ARTICLE HISTORY}

Received 1 March 2016

Accepted 2 August 2016

\section{KEYWORDS}

Alcobaça; scriptorium; illuminated manuscript; breviary; Cistercian; liturgy; pigments; silver

\section{Introduction}

The monastery of Alcobaça (Mosteiro de Santa Maria de Alcobaça) was founded in 1153, ${ }^{1}$ and the manuscripts necessary for the functioning of monastic life would have been, as was common within Cistercian houses, supplied by the mother-abbey. ${ }^{2}$ Activity in the monastery's scriptorium probably started during the last ten to fifteen years of the twelfth century, ${ }^{3}$ and the scriptorium remained active until at least the sixteenth century.

CONTACT Catarina Fernandes Barreira fernandesbarreira@gmail.com

${ }^{1}$ See Gomes, "Revisitação a um velho tema", 28.

${ }^{2}$ The necessary manuscripts were normally: missale, regula, liber usuum, psalterium, lectionarium, hymnarium, collectaneum, antiphonarium, gradale. See Canivez, Statuta Capitulorum, 15; and Bondéelle-Souchier, "Trésor des moines", 91-2.

${ }^{3}$ As confirmed by the studies of Adelaide Miranda on the illumination of Alcobaça manuscripts: Miranda, "Iluminura românica em Santa Cruz de Coimbra e Santa Maria de Alcobaça"; and the bookbinding studies of Nascimento et al., Encadernação portuguesa medieval; and Nascimento, Le scriptorium d'Alcobaça, 149-62.

(c) 2016 Informa UK Limited, trading as Taylor \& Francis Group 
Despite some losses, the abbey's library is one of the most impressive which survives to the present day (compared to other Cistercian libraries ${ }^{4}$ ), with a total of 466 codices $^{5}$ (these were mostly produced in the abbey's scriptorium, but were also acquired ${ }^{6}$ or supplied by other Cistercian abbeys). ${ }^{7}$

The manuscript Alc. 54, known as the winter Breviary (Figure 1), has not been studied in detail prior to this work, ${ }^{8}$ and we intend to confirm its origin in the scriptorium of Alcobaça based on the study of the liturgy on the one hand and on laboratory analysis of the materials used to produce this manuscript, on the other. Following the extinction of the Portuguese religious orders in $1834,{ }^{9}$ it was integrated into the Biblioteca Nacional de Portugal (BNP).

Through a detailed analysis of a little-known manuscript in the collection of the monastery of Alcobaça, this paper aims to open a new avenue of investigation by addressing the changes that occurred at this monastery's scriptorium at the end of the thirteenth and the beginning of the fourteenth centuries, in terms of style and the materials used for colour, and discuss what induced these transformations. Alcobaça's manuscripts from earlier periods (twelfth century and first half of the thirteenth century) do not exhibit filigree and usually do not have historiated initials like those observed in this manuscript. Thus, a major question arises: What changes occurred in the scriptorium of Alcobaça that explain the evolution in the illuminated decoration observed in Alc. 54? Also, the decorated and historiated initials (Figure 2) have degraded a great deal at a pictorial level, creating a natural point of interest (Figure 3). Thus, a second question arises: were the dark colours that we observe now actually black in the original manuscript?

To address the changes observed in the colour palette, we build on our previous studies on the colour of the manuscript illuminations produced in the scriptorium of Alcobaça monastery in the twelfth and thirteenth centuries, comparing the results with those from the present study of the fourteenth-fifteenth-century breviary Alc. 54. From an interdisciplinary perspective, we will compare the evolution of style and see if it correlates with the changes in the colour palette (pigments, dyes, binding medium). Although it is possible to see with the naked eye that the colour palette changed between the thirteenth and the fourteenth centuries, there are relevant but invisible features such as pigment and binding medium characterisation that only advanced analytical methods may disclose.

${ }^{4}$ On this subject, see Jamroziak, The Cistercian order in Medieval Europe, 210; Bondéelle-Souchier, Bibliothèques cisterciennes dans la France médiévale, and Bondéelle-Souchier, "Trésor des moines", 97.

${ }^{5} \mathrm{~A}$ total of 456 codices, as reported in the Inventário dos Códices Alcobacenses, plus eight kept in the Torre do Tombo, which were added to those at the BNP in the 1990s. Over 350 of these surviving manuscripts date from the second half of the twelfth and the end of the fifteenth centuries: in Nascimento, "Em busca dos códices alcobacenses perdidos", 205-6. Two manuscripts, BNP Alc. 64 and BNP Alc. 132, disappeared from the National Library in the 1940s: in Nascimento, "Em busca dos códices alcobacenses perdidos", 208. Recently, two more manuscripts were added, one in the National Library of Australia: Barreira, "Questões em torno dos Ordinários do Oficio Divino de Alcobaça", 111-32, and another in Salzedas in Rêpas and Barreira "Place and Liturgy in an Illuminated Ritual from Santa Maria de Alcobaça".

${ }^{6}$ For example, BNP Alc. 261, Commentarium in Sententiarum Librum by Thomas Aquinas, was copied by pecia and purchased by decem libras turonensis for ten Tournai pounds in 1285, as mentioned by Pereira: "A Pecia em manuscritos universitários", 263-4. In this context we also refer to BNP Alc. 417, which was purchased for 60 Bolognese pounds.

${ }^{7}$ This is the case of BNP Alc. 143, from the Lorvão scriptorium - in Nascimento, "Tempos e livros medievos: os antigos codices de Lorvão", 402 - but also the case of BNP Alc. 85, a paper Devocionário, dating from 1558, from the Bouro Abbey, according to the Inventário dos Códices Alcobacenses, 79.

${ }^{8}$ The historiated initial for Saint Stephen, among other illuminated representations of the Saint in Alcobaça manuscripts, is the subject of a forthcoming article by Barreira, "O martírio de Santo Estevão em três manuscritos iluminados da abadia cisterciense de Alcobaça".

${ }^{9}$ See Barata, Os livros e o liberalismo, 2003. 

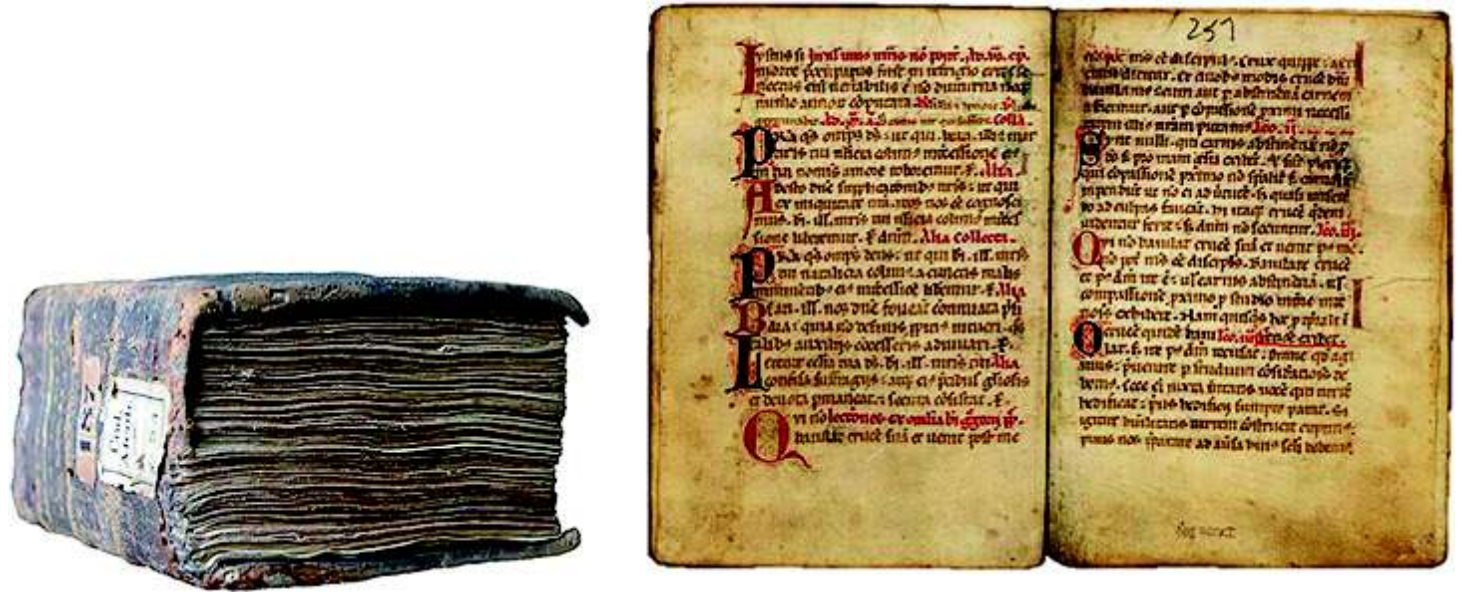

Figure 1. Winter-season breviary (BNP, Alc. 54): (left) the current bookbinding of the codex dates to the end of the seventeenth century and beginning of the eighteenth century and presents pasteboards covered in a dark brown leather, forming a full plain dark brown leather binding. The spine is flat and presents a label "BREVIARIUM CISTERCIENSE", obtained by gold-tooling decoration; (right) Alc. 54 open on the folios $256 \mathrm{v}$ and 257.

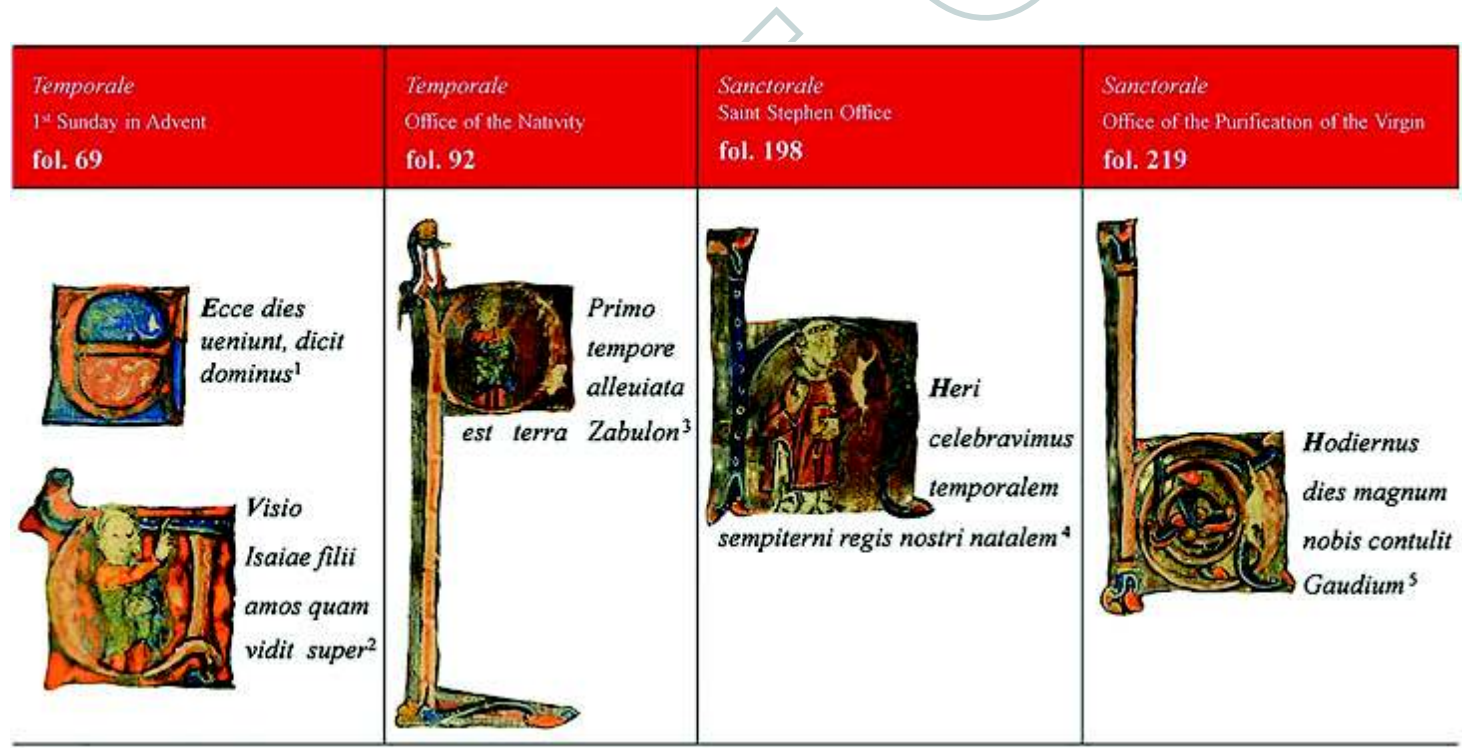

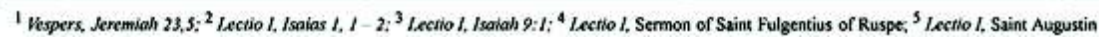

Figure 2. Historiated and decorated initials in Alc. 54.

Based on research into the materials of colour we will delve further into the identity of the Alcobaça scriptorium and its monastic production.

To fully answer these questions, this work promotes collaboration between science and art, specifically between conservation, chemistry and art history, and will, for the first time in Portugal, situate a fourteenth-century little-known manuscript in the context of a major scriptorium production. ${ }^{10}$

\footnotetext{
${ }^{10}$ Melo et al., "Colour: An Interdisciplinary Approach"; Melo, Castro and Miranda, "Colour: Between Beauty and Meaning"; Muralha, Miguel and Melo, "Micro-Raman Study Cistercian Manuscripts"; Melo and Miranda, "Secrets et découvertes en couleur".
} 

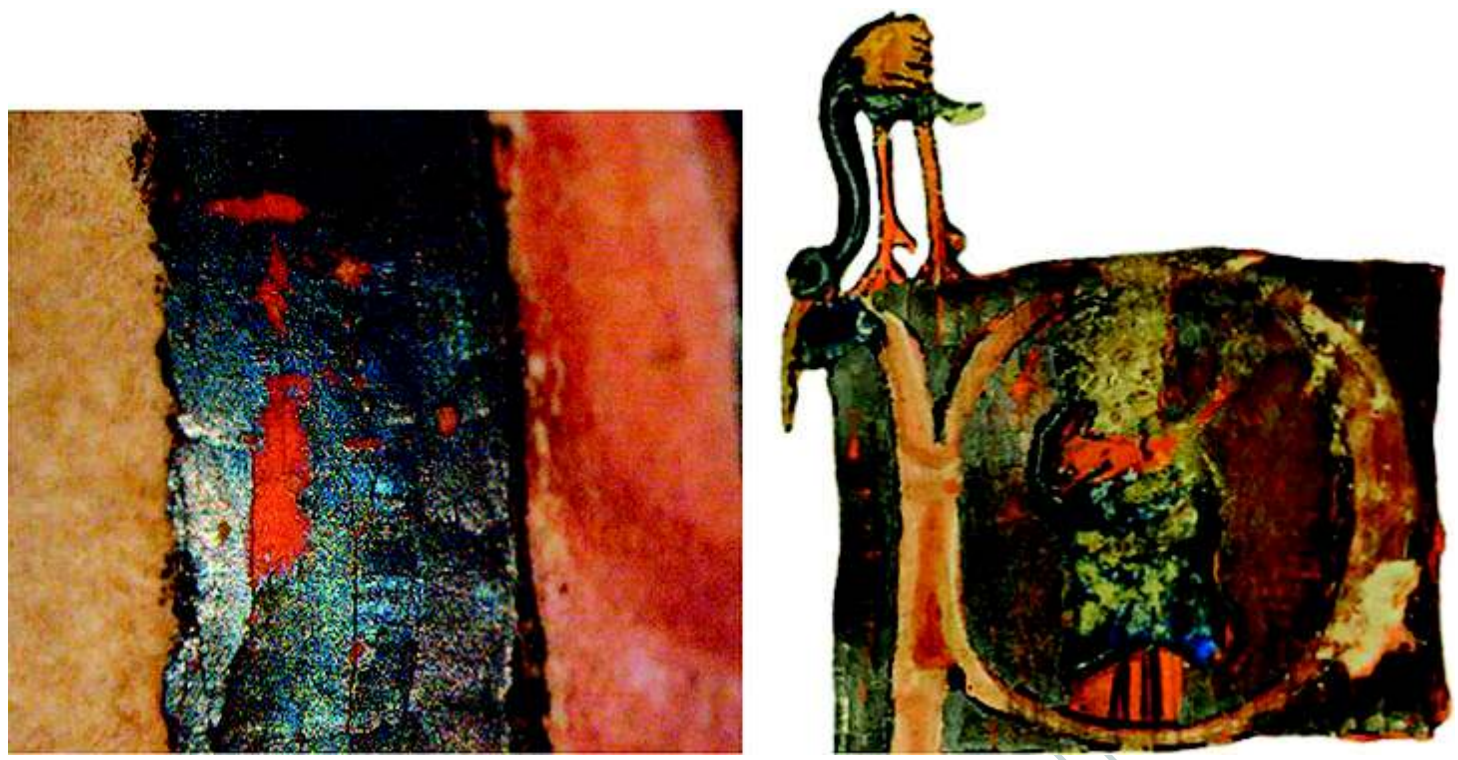

Figure 3. Colour application in the historiated initial on fol. 92 (right), Alc. 54 (fourteenth century): detail of the silver metal foil applied over red preparation (left).

\section{The colour palette employed by the Alcobaça scriptorium}

This is the first study of the colour materials used in a fourteenth- and fifteenth-century Alcobaça manuscript. For this reason, we will summarise, not the state of the art for the fourteenth-fifteenth centuries, but the key results obtained from our studies for the first production phase of the scriptorium, from the twelfth century and the first half of the thirteenth.

The palette employed by the scriptorium of Alcobaça monastery to start its library in the twelfth and thirteenth centuries was a rich one, and long-lasting colourants that had great chromatic impact ${ }^{11}$ were selected. ${ }^{12}$ The colours used the most, which we classify as dominant colours, were green and reds, identified by some authors as "liturgical"13 colours, or those with high symbolic value such as lapis lazuli blue. ${ }^{14}$ The raw materials for pigments and dyes used in this period included natural pigments (vermilion, orpiment, lapis lazuli), synthetic inorganic compounds (bottle green, minium, lead white and bone black) and dyes (lac-dye red and indigo blue). These colours came from the "four corners of the world": lac dye from India and lapis lazuli from Afghanistan reflect the extensive trade routes built by the Islamic world. ${ }^{15}$

The colourants used on the illuminations may have come from far away, but it was at the monastic scriptoria itself that they were prepared and made into paints. They were prepared by adding a protein (binding media) and fillers, such as chalk or gesso, which gave "body" to the colourant (pigment or dye) in order that it could be painted. ${ }^{16}$ At the

${ }^{11}$ Saturated colours were applied "pure", i.e., without mixing colourants.

${ }^{12}$ Melo, Castro and Miranda, "Colour: Between Beauty and Meaning", 174-8.

${ }^{13}$ We used the term "liturgical colours" following Pastoureau, "Le temps mis en couleurs", 111-35. See also Brunner, "Colour in religion", 535

AQ1 ${ }^{14}$ Pastoureau, "Blue: The History of a Color"; Parodi, "Lapislazzuli".

AQ2 ${ }^{15}$ Castro et al., "Combining SERS and Microspectrofluorimetry with HART"; Parodi, "Lapislazzuli," 21.

${ }^{16}$ Melo, Castro and Miranda, "Colour: Between Beauty and Meaning"; Melo et al., "Spectroscopic Study of Brazilwood Paints". 
Alcobaça scriptorium, colours were applied on the parchment support as protein temperas, with formulations that we can classify as complex. ${ }^{17}$ If any varnishes were used, they have left very few traces.

\section{The breviaries}

The breviary is the book used to celebrate the Liturgy of the Hours, and as such contains the chants such as responsories, versicles and antiphons, but also prayers, hymns and readings of the Liturgy of the Hours. With respect to their internal structure, the Alcobaça breviaries $^{18}$ usually include the following sections: Calendar (absent from this manuscript), Psalter, Temporal, Sanctoral and Common of saints (Figure 4). ${ }^{19}$ Generally, the start of the most important sections - Psalter, ${ }^{20}$ Temporale and Sanctorale - or the more significant feast days in those sections were punctuated with a historiated, decorated or 'puzzle' filigree initial (Figure 4).

\section{Analysis of the book structure, texts and illuminations}

The Alcobaça winter Breviary (Alc. 54) measures $157 \times 114 \mathrm{~mm}$ and contains a total of 340 folios organised into thirty-one quires; most are composed of six bifolios, and the first twenty-seven quires belong to the original corpus of the manuscript (fol. $1 \mathrm{r}-\mathrm{fol}$. $309 \mathrm{v}$ ), dating to the fourteenth century. The remaining four quires were added in the fifteenth century - at two different points, as is clear from the organisation of the sections, the types of text and the illuminated decoration (fols. $310 \mathrm{r}-327 \mathrm{v}$ and fols. $328 \mathrm{r}-340 \mathrm{v}$ ).

The current bookbinding of the codex possibly dates to the end of the seventeenth century, or the start of the eighteenth, although it is hard to assign a precise moment given the lack of characteristic identifying elements. The book is bound within pasteboards (which were already in use at the end of the fifteenth century) covered in a dark brown leather, forming a full and plain dark brown leather binding with speckled decoration (common since the seventeenth century). A mixture of animal glue and starch was used for the spine and the endpaper adhesion. The textblock is sewn all the way along on three raised cords that are laced into the boards. The parchment endleaves make use of the material, and contain writing, and the first fly-leaf is composed of handmade paper, containing a description of the manuscript, and is probably contemporaneous with the current binding. ${ }^{21}$ The spine is flat and is reinforced with linen lining (which probably

\footnotetext{
${ }^{17}$ Complexity in a medieval paint formulation arises because together with the main ingredients (colorant plus polymer binder) a wide range of additives was included to improve durability, application and good thermomechanical performance. The complexity of the formulation was necessary to deliver high-performance paints. At present, it is very difficult to determine all the ingredients as many additives are found in low concentration or may have disappeared over time.

${ }^{18}$ Regarding the celebration of the Divine office in a Cistercian context, as well as the specificities related thereto, there are two important sources for study, which we have used in this article: the work of Chrysogonus Waddell, who edited the Primitive Cistercian Breviary (dated to 1132); and more recently, Claire Maître, who published the Clairvaux Breviary (from 1247). Both are important tools for those who study Cistercian liturgy and its evolution because they offer two accounts of the celebration of Divine office at different moments.

${ }^{19}$ See Leroquais, Les Bréviaires manuscrits, 15.

${ }^{20}$ The Psalter contains filigree "puzzle" initials and the eight psalms that "divide" the set of 150; or in other words, it highlights Psalms 1, 26, 38, 52, 68, 80, 97 and finally Psalm 109 - Sousa, Sacra Pagina, 28.

${ }^{21}$ Sousa Viterbo questions whether the monk, author of the index from 1775, was also responsible for the sheets of paper with the attribution and description of the book in Viterbo, "Calígrafos e iluminadores portugueses", 408. On this, see: Nascimento, "Percursos do livro na História da Cultura Portuguesa Medieval", footnote on 293.
} 

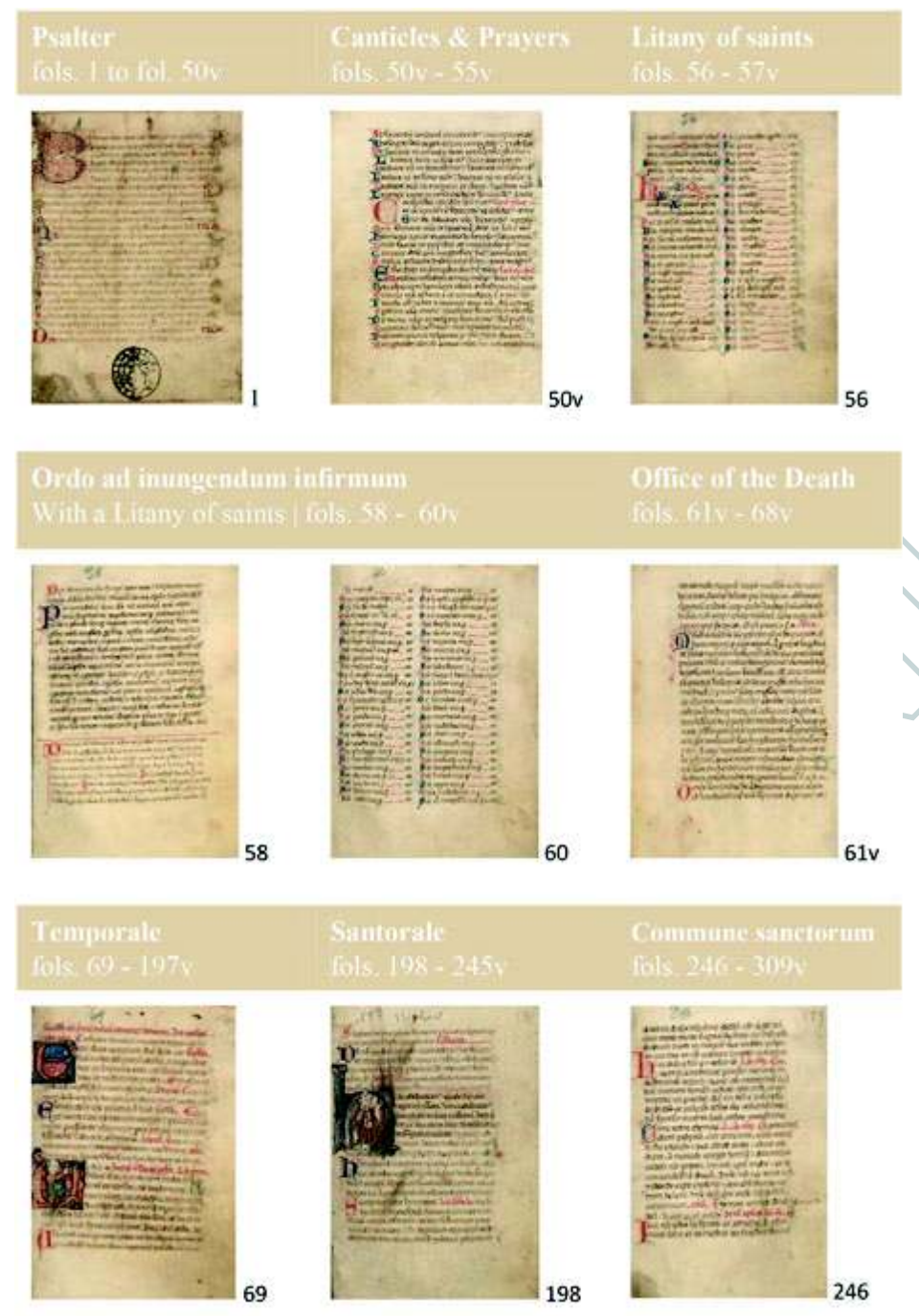

Figure 4.

leads us back later in time). On the second panel on the leather binding, there is a label that reads "BREVIARIUM CISTERCIENSE"; this was framed by gold decoration using a hand tool that was in use in the eighteenth century.

\section{Description of the texts and liturgical analysis}

Liturgical manuscripts are the most interesting in a monastic library because they testify to the evolution of liturgy, as well as the important relationship with the community of monks. 
After the Psalter, the Canticles and Prayers, we have the first Litany of Saints in this manuscript. The Litanies are an important identifying element ${ }^{22}$ because they cover the local saints of highest devotion. This litany raises a few questions because, after the first martyr, Stephen, we have Saturnine, martyr and bishop of Toulouse. The connection between this litany and its French counterparts is also reinforced by the presence of Justus and Pastor, Dionysus and his companions, Martialis (of Limoges), Hilary (of Poitiers) and Martin (of Tours). Finally, the presence of Mary of Egypt, uncommon in the Litanies of Alcobaça and Fides (affiliated with Conques), once again underscores the connection of the litany to France. ${ }^{23}$ As we will discuss in the two next sections, in the original corpus the French influence on the manuscript is also noticeable in the formal and iconographic characteristics of the historiated and decorated initials which are also present in other manuscripts including Alc. 26 and Alc. 376. This influence was probably linked to Alcobaça's filiation - Clairvaux - through the presence of Alcobaça abbots in the General Chapters.

Nevertheless, although this litany has a direct relationship with the south of France, it does not mean that this manuscript was not copied in the Alcobaça scriptorium, using another manuscript as a model. In fact, the Pontifical of Coimbra ${ }^{24}$ (Santa Cruz 59), dating from the second half of the twelfth century, for reasons unknown to us also included a litany that was characteristic of the south of France; this litany concerns the ritual Ad consecrandum electum episcopum in fol. 71r. This pontifical, whose origin was the scriptorium of Santa Cruz de Coimbra, a community of Canons Regular of Augustin, was influenced, from a liturgical point of view, by St Rufo of Avignon. ${ }^{25}$ Thus, our proposal is that the litany of the winter Breviary could have been influenced by this twelfthcentury pontifical from Coimbra monastery - because the connections between the two scriptoria, Coimbra and Alcobaça, the most important medieval scriptoria in Portugal during the Middle Ages, were close, and have been mentioned by Nascimento and Gomes. ${ }^{26}$ Both monasteries had a pact of spiritual collaboration, which is attested by a testimony in a manuscript from Alcobaça (Alc. 331, from the thirteenth century). ${ }^{27}$

We now move on to the Ordo ad inungendum infirmum, a sacrament for anointing the sick, and Ordo ad inhumandum fratrem mortuum, which, just like the previous one, is common Cistercian liturgy ${ }^{28}$ and common among other liturgical manuscripts, namely breviaries, compiled in Alcobaça: the two Ordines appear in manuscripts Alc. 29, Alc. 66, Alc. 67 (from 1442), Alc. 165, Alc. 166 and a Ritual ${ }^{29}$. Both Ordines of Alcobaça's breviaries proceed from the Dijon BM ms. $114^{30}$ (these rituals were copied between fols. 149

\footnotetext{
${ }^{22}$ Litanies reflect "the piousness of the community to which it is directed": in Bragança, "Pontifical de Braga do séc. XII", 332.

${ }^{23}$ As Oliveira Bragança has already detected from other manuscripts such as the twelfth-century Pontifical de Braga ${ }^{23}-$ in Bragança, "Pontifical de Braga do séc. XII", 334 - and the Breviary and Missal from the twelfth and thirteenth-centuries in Bragança, Liturgia e espiritualidade na idade média, 421-37.

${ }^{24}$ Public Municipal Library of Porto, BPMP Ms. 353. Nascimento and Meirinhos, "Catálogo dos Códices da Livraria de mão", 275 - 277; Cepeda and Ferreira, Inventário dos Códices Iluminados até 1500. Vol. 2, 171.

${ }^{25}$ The presence of Saturnine in the Litany and the other saints connected with Toulouse in the Ordo mentioned continues to raise problems for experts who study the manuscripts of Santa Cruz de Coimbra: Bragança, Liturgia e espiritualidade na idade média, 84.

${ }^{26}$ Nascimento, "Concentração, dispersão e dependência", 61-86; Gomes, "Relação entre Santa Cruz de Coimbra", $257-303$.

${ }^{27}$ Nascimento, "Percursos do livro na história", 309.

${ }^{28}$ According to Bragança, Liturgia e espiritualidade na idade média, 425

${ }^{29}$ Rêpas and Barreira, "Place and Liturgy in an Illuminated Ritual from Santa Maria de Alcobaça".

${ }^{30}$ According to Thomas Falmagne, this manuscript was copied between 1183 and 1188; see Falmagne, Les Cisterciens et leurs bibliothèques, 17.
} 
and 151v). ${ }^{31}$ We also find both Ordines in a manuscript from Clairvaux, the Troyes BM ms. 1706, dating from the second half of the twelfth century. The sacrament of anointing the sick somewhat resembles the Roman Pontifical studied by Andrieu and Mattoso, ${ }^{32}$ especially concerning some orationes (but these are not necessarily in the same order). ${ }^{33}$

In relation to the texts common to Cistercian liturgy and the question of Cistercian consensus, ${ }^{34}$ we detected an interesting aspect of this breviary, at both the Temporale as well as the Sanctorale level. Concerning the daily celebration of the Divine Office within the Cistercian context, that Matins office was divided into three nocturns, each including four readings, to make a total of twelve lessons. ${ }^{35}$

In this breviary, with respect to the responsory (and versicles) of the three Matins nocturns that comprise the four Sundays in Advent, we find the same responsory in three other Alcobaçan manuscripts, Alc. 8, Alc. 10 and Alc. 66. Furthermore, the same responsory is used during the four Sundays of Advent of Alc. 54, when compared with the Primitive Cistercian Breviary ${ }^{36}$ as well as the Clairvaux Breviary of $1247^{37}$ However, the long readings do not always coincide with the chosen section: generally Lectio $I$ and $I I$ are exceptions, as is the gospel of the day. Yet, the readings for other hours coincide, to wit: Lauds, Prime, Terce, Sext, None and Vesperas. On Advent feriales, the readings also coincide. This is also the case, for example, for the Die Nativitatis Domini: the responsories, versicles and antiphons coincide, but not the long readings, except for the Lectio I and the readings that are excerpts from Patristic Fathers (readings $I V, V, I X, X, X I$ and $X I I) .{ }^{38}$ How can we justify this apparent non-conformity in the chosen readings? ${ }^{39}$ Even among manuscripts with a large chronological range, for example, between this winter Breviary and the Breviary Alc. 66, dated around 1300-1317, we see this in the readings. Thus, another question arises: does this difference in readings tell us that the breviaries of Alcobaça were not being copied from each other?

The long readings of the two nocturns chosen are from Isaiah, but from different parts of that book: this is the case, for example, for the first Sunday of Advent. All readings were chosen from Isaiah, chapter 1 , but from different excerpts of the text. For the third nocturn, the four readings should be taken from the Church Fathers, in this case, from Bede's Commentaries on Scripture. ${ }^{40}$ Therefore, the liturgical non-conformity mentioned above is not confirmed, as excerpts were chosen from different versicles for the nocturns' readings of each manuscript. The question of the absence of uniformity does not arise

\footnotetext{
${ }^{31}$ The Dijon BM ms. 114 was an exemplar, a guide to the copy of other manuscripts, as stated in fol. 1v: "In hoc volumine continetur libri ad divinum officium pertinentes quos utique non decet in ordine nostro diversos habere. Sunt autem hic in unum corpus ea maxime ratione redacti ut presens liber sit exemplar invariable ad conservandam uniformitatem et corrigendam in aliis diversitatem." In Berman, The Cistercian Evolution, 244.

${ }^{32}$ Mattoso made a comparison between these two Ordines and the Roman-Germanic Pontifical from the tenth century and concluded that "from the thirty-five collections of the Pontifical, twenty-six are common to the ritual of Alcobaça, although almost entirely shifted to other moments of the sequence." In Mattoso, Obras completas. Poderes invisíveis. O imaginário medieval, 68.

${ }^{33}$ Andrieu, Le pontifical romain au moyen-age, 266-84.

${ }^{34}$ On this subject: Auberger, L'unanimité cistercienne primitive ; Falmagne, "Le réseau des bibliothèques cisterciennes", $195-$ 222 ; Falmagne, Les Cisterciens et leurs bibliothèques, 16-17.

${ }^{35}$ Herder, "Liturgy and the Spiritual Experience", 172.

${ }^{36}$ Waddell, The Primitive Cistercian Breviary, 103-33.

${ }^{37}$ Maitre, Le bréviaire cistercien Troyes, 72-102.

${ }^{38}$ Concerning readings recommended for the nocturns of the Temporal, see Maitre, Le bréviaire cistercien Troyes, 27.

${ }^{39} \mathrm{~A}$ deviation of a similar type is detected in Valbona manuscripts in Herder, "Liturgy and the Spiritual Experience", 183.

${ }^{40}$ Giles, The Complete Works.
} 
because, in general, each breviary follows the guidelines concerning Cistercian liturgical observation. A similar dynamic can be observed in other Cistercian abbeys. ${ }^{41}$

In Alcobaça, successive singers were responsible for the selection of different excerpts from Isaiah and Bede for the readings of Matins, in this case, the first Sunday of Advent, and perhaps whenever it was necessary to copy another breviary. To verify this, we examined other manuscripts of Alcobaça, in particular the texts that supported the internal life of the abbey, the Ordinaries of the Divine Office ${ }^{42}$ and the Books of Uses, ${ }^{43}$ and confirmed that, in Alcobaça, the cantor was responsible regarding the choice of readings.

The Sanctorale begins with the Office of Saint Stephen, which does not start in tandem with Advent, an aspect in common with the Primitive Cistercian Breviary and the Clairvaux Breviary. Most of the liturgical manuscripts of Alcobaça start with Saint Stephen, and the same thing happened with the manuscripts of Clairvaux. Also, the manuscript Dijon BM ms. 114 begins its Sanctorale with Stephen (fol. 64v). We do not believe that this beginning of the Sanctorale, instead of Saint Andrew, can be considered an archaism. ${ }^{44}$ This tradition is common in Cistercian manuscripts. ${ }^{45}$

The Common of Saints begins on fol. 246, and the initial core of this winter Breviary ends on fol. 309v, with the Office Corona Domini and the hymn of Saint Agatha the Virgin. Next there are two additions from the following century: the first goes from fol. $310 \mathrm{r}$ to fol. $327 \mathrm{v}$ and is a set of hymns. From fol. $328 \mathrm{r}$ onward, the second addition begins: after the Corpore Christi, there is another Litany with the Cistercian saints (Bernard and Robert) that is also common to other Alcobaçan manuscript Litanies (Alc. 137, a psalter from 1346 and breviary Alc. 189).

Concerning the two distinct additions from the fifteenth century, it is worth noting that fol. 339v and fol. 340r contain a text written in 1491, by a monk, Francisco da Costa, in which he states that this breviary was at Alcobaça Abbey. Frei Francisco received the breviary as a present from Abbot Isidoro of Alcobaça (r. 1488-1493) between 1488 and November 1490, when he left for St Paul of Almaziva. ${ }^{46}$ According to Maria José A. Santos, this monk went to St Paul's monastery in November 1490 and stayed there

${ }^{41}$ According to Thomas Falmagne : "Donnons un autre indice d'une pratique liturgique qui n'était pas identique dans l'ensemble de l'Europe cistercienne : les lectures patristiques de l'office ( ... .) Plutôt que d'invoquer la perte récurrent de lectionnaires-type qui, à l'instar d'autres livres liturgiques, pourraient se révéler obsolètes plus ou moins rapidement, ne peut-on suggérer que bien souvent le chantre organisait lui-même les lectures patristique à l'office à partir de collections antérieures, voire des œuvres originales des Pérès, que l'on conserve en principe dans la bibliothèque commune du monastère?" Falmagne, Les Cisterciens et leurs bibliothèques, 17.

42 Barreira, "Questões em torno dos Ordinários", 131-52.

${ }^{43}$ One Ordinary, Alc. 209, on fol. $2 r$ and fol. $2 v$ on the first Sunday of Advent, mentions the reading - from Isaiah - and that the cantor is responsible for the selection of readings. In the Book of Uses Alc. 208, dated 1415, we have the following statement: "Start the matins of the first Sunday of Advent reading the book of Isaiah and so on ( ... ) as the cantor says" (Alc. 208, fol.4v). This manuscript mentions again: "[That] the Book of Isaiah be read in its entirety during Advent, not only in church but also in the refectory and as may please the cantor (....) And the cantor should dole out, between vigils and refectory readings, the lessons to be read for Advent" (Alc. 208, fol.104v).

${ }^{44}$ Lebigue, Initiation aux manuscrits liturgiques, 23.

45 According to Yolanda Zaluska and Marie Françoise Damongeot: "Le début du sanctoral à saint Etienne (26 décembre) indique que le manuscrit appartient à un groupe de manuscrits qui séparent le temporal du sanctoral 'de façon radicale', autrement dit, en détachant d'une manière qui semble arbitraire, les trois festivités que font liturgiquement partie du «bloc» de Noel ...". Zaluska and Damongeot, "Analyse liturgique du Lectionnaire de la messe", 108.

${ }^{46}$ This circulation of manuscripts between Portuguese Cistercian abbeys at the end of the fifteenth century is documented in another manuscript, an Ordinary of the Divine Office, which has already been studied by us: Barreira, "Questões em torno dos Ordinários", 111-32; Barreira, "Ficha de catálogo do n 8", 125 - 126; and Barreira, "A iluminura portuguesa no século XV", 161-90. 
until December $1498 .{ }^{47}$ One year later, he wrote the testament in the manuscript, with the idea of returning it to Alcobaça Abbey, to which it belonged, as if it were his obligation. We are unsure of the actual date on which it was returned, but we know that the abbey had the manuscript by 1775 , when Joaquim Francisco de Sá prepared the Index. ${ }^{48}$

My Lord Jesus Christ, I, Friar Francisco da Costa, humble myself before Your Holy Majesty every day of my short life, made greater by your holy Catholic faith. If perchance death may snatch me unaware and so that my enemies will not catch me offhand, I confess to You (...) my Lord and Redeemer to whose hands I commend my soul and body (....) And such being what the Holy Mother Church expects and believes, I hope for this reason to enjoy good health for a long time. I place Your judgment and my sins before [the] witnesses (....) For which I pray and commend that this Breviary of mine, with all the good deeds that I have made for it, be taken to the monastery of Alcobaça, where I am a professed brother, because Abbot Dom Ysidoro has given it to me during my life. Written in the monastery of Sam Paulo, on the $9^{\text {th }}$ day of September, one thousand IIIIC LRI [1491]. ${ }^{49}$

This beautiful text arose because the monk wanted to be prepared for death, lest it appear "lately" (unexpectedly) and he was not properly prepared, which would burden his soul (i.e. the manuscript would not be returned on his death because no one knew of the requirement). Finally, fol. $340 \mathrm{v}$ has a prayer and a design on the last folio of the manuscript, Ad reperiendum pasca $i$ calendário, a "stanza of new verses in praise of the Virgin" 50 and an interesting drawing of a monk in profile, set over the poetry. ${ }^{51}$

Taking the Sanctoral into account, we can highlight an inconsistency when analysing the offices: the presence of the abbot Antonii authorized by the General Chapter in 1260 and the absence of the vigil of the Purification of the Virgin and its octave, authorized by the General Chapter in 1294, lead us to suggest that this Breviary was copied between 1260 and 1294. But the Sanctoral has the office of Saint Gregory, authorized by the General Chapter in 1300. One hypothesis to explain this is that the core of this manuscript, copied around 1300, reproduces an older manuscript, in use after 1260. Also the presence - in the margin - of the feast of Thomas Aquinas (established in 1324) and the addition with the Office of Corpus Christi ${ }^{52}$ confirm that the nucleus of the manuscript was copied before 1318, probably between 1300 and 1317 .

${ }^{47}$ Santos, Vida e morte de um mosteiro cisterciense, 117.

${ }^{48}$ Sá, Index codicum Bibliothecae Alcobatiae, 85.

49 "Meu Senhor Jhesus Christo eu frey Francisco da Costa protesto diante a Tua Sancta Magestade todollos dias da minha vida viver e morrer em a Tua santa fee catholica. Se per ventura a morte a desora me aRebatar por que hos meus inmigos nom me enganem naquela ora de agora por entonce e de entonce por agora te confesso (... ) meu Deus e meu redemptor em as maaos do qual a minha alma e o meu corpo encomendo. E sendo isso mesmo o que a madre Santa lgreja cree e tem esperando por esto saude perduravel $E$ ponho antre testemunhas ho teu juizo e os meus pecados. (...) Esso meesmo rogo e encomendo que este meo briviairo com as bemfeiturias que nelle tenho fectas seja levado ao moesteiro d'Alcobaça, donde som professo, porque dom abbade Ysidoro mo deu em minha vida. Fecto no mosteiro de Sam Paulo, a IX dias de Setembro de mil IIII LRI anos (1491). Frater Francisco da Costa" We are deeply grateful to the historian and palaeographer Luis Miguel Rêpas, who transcribed the text and helped us with its interpretation.

${ }^{50}$ Anselmo, Inventário dos códices alcobacenses, 53.

51 "Contemplay hum tal prazer /Contemple quem o sentir/Quando ao ceu me vir subir/O meu filho puder ver/E meu corpo e alma notai ...."

${ }^{52}$ Concerning the dating of manuscripts using the Liturgy: Leroquais, Les Bréviaires manuscrits; Legendre, "Tools for Dating and Localizing Manuscripts", 186 and 187. 


\section{Illuminated initials}

\section{Historiated}

This winter Breviary has five decorated and historiated initials (see Figure 2). The Temporale begins on fol. 69r, in Saturday's Vesperas in Adventu Domini, and is highlighted with two initials, one decorated and the other historiated, the latter of which is associated with the Lectio I. The iconographic theme represented in the initial is Prophet Isaiah, arm raised to prophesy about Judah and Jerusalem (Isaiah 1: 1-2). Garnier, who analyses the hand gesture, suggests that this is a gesture of authority and command, and, in this case, of the prophet's authority to reveal a message from God. ${ }^{53}$

On fol. 92, regarding the Office of the Nativity of the Lord, we find another historiated initial, also associated with Lectio I. In this case there is another masculine figure placed inside the initial - another representation of Isaiah, whose prophetic text provided this reading (Isaiah 9: 1). Perched atop this initial is a stork, which within the context of this breviary may be interpreted as an association to the Isaiah prophecies - an antiphon to what is written after it: veritas de terra orta est et iustitia de caelo prospexit (Psalm 84: 12). However, there are two other manuscripts in Alcobaça from this period with a significant number of birds represented in the margins: the aforementioned Missal Alc. 26 and the Compendium Theologicae Veritatis Alc. 376 (dated 1332). Concerning the presence of birds Mary Carruthers says that they were common and a long-lasting element in illuminated books. She states: "Such images are not iconographical, nor do they illustrate or explain the content of a particular page." Nevertheless, Elizabeth Hunt mentions that the presence of birds in manuscripts was probably an indirect influence of the circulation of illuminated copies of the Aviarium of Hugh of Fouilloy: ${ }^{55}$ Alcobaça had an illuminated Book of Birds from the end of the twelfth century, Alc. $238 .^{56}$

The Sanctorale begins on fol. 198r with Saint Stephen (Figure 2). Within the He see a representation of the saint, dressed like a deacon, with his attributes: blood running from his head and a book in hand. His closed hand is holding either a stone or a palm. Stephen was one of the seven deacons full of faith and the Holy Spirit whom the apostles recruited to their mission to spread the word of God. After performing miracles among the people, Stephen was betrayed by the priesthood and was presented before a tribunal, where he had a vision that transformed him (his face looked like an angel, Acts 6: 15); his sentence was expulsion from the city and death by stoning. This was the biblical story that served as the inspiration for later narratives on Stephen's martyrdom and was one of the key sources for the iconographic construction of the saint. He is represented in one of two different ways: the first, depicting the saint and his attributes, the second his death by stoning. Illuminated texts dating back as far as the ninth century contain depictions of Stephen. ${ }^{57}$ As

${ }^{53}$ Garnier, Le langage de l'image au Moyen Age, 167. This gesture is inherited from ancient art, and was transferred to the artistic field due to the scope of rhetoric used by speakers. See Schmitt, La raison des gestes dans l'Occident médiévale, 446; and Miguélez Cavero, "El dedo índice como atributo regio de poder en la iconografía románica de la Península Ibérica", $325-40$.

${ }^{54}$ Carruthers, The Book of Memory, 323.

${ }^{55}$ Hunt, Illuminating the Borders, 28.

${ }^{56}$ Castro, Melo and Miranda, "The Secrets Behind the Colour", 31-55.

${ }^{57}$ One of the ancient illuminated representations of Saint Stephen belongs to Sacra Parallela of John Damascene, a manuscript from the ninth century: BNF, Paris, grec 923, fol. 40. 
well as the biblical account which is important for the study of the iconography of the saint, there is also an additional source of important writings, ${ }^{58}$ the most significant of which is by Jacques de Voragine, who in his Flores seu legendae sanctorum states that Stephen's feast is celebrated on this date, following the birth of the Lord, because it is an homage to the Christian Church's first martyr. Alcobaça had a copy of the Legenda in its library, dating from the end of the thirteenth or the start of the fourteenth century - a manuscript of French origin, copied by pecia ${ }^{59}$ (BNP, Alc. 40: fol. 24rfol. 27r) - and one other manuscript from the fourteenth century (BNP, Alc. 39: fol. $18 \mathrm{v}$-fol. 21r). In Alcobaça, there are at least two depictions of the saint in liturgical manuscripts: one in the already mentioned Missal Alc. 26 and in the Matinal Breviary Alc. 66, although in these last two codices the saint is depicted in the context of his stoning.

Now we move on to the subsequent decorated initial, which was related to the Office of the Purification of the Virgin, celebrated on 2 February. This initial presents the same dynamic characteristics as those prior. The creation of a decorated, not historiated, initial to denote the Office of the Purification of the Virgin is significant, within a hierarchy of illuminated: historiated for Saint Stephen, decorated for the Purification Virgin. In the Proper of Saints, it denotes the feast of Saint Benedict, celebrated on 21 March, and on fol. 219 it denotes the Annunciation, celebrated on 25 March.

The historiated and decorated initials have many points in common with two other manuscripts at the abbey that were copied in the first half of the fourteenth century, in the scriptorium at Alcobaça: ${ }^{60}$ Missal Alc. 26 and the Compendium Theologicae Veritatis, Alc. 376. In all three manuscripts, we may note the similarity with the initials in French manuscripts, in particular those from the second half of the thirteenth century and the start of the fourteenth century, contemporaries of the winter Breviary. Because of the connections between Alcobaça and the College of Saint Bernard in Paris - Alcobaça sent one or more monks to study in Paris - the Abbey's library contains a significant number of manuscripts originating from French scriptoria, notably Bibles ${ }^{61}$ and Parisian university manuscripts copied by pecia. ${ }^{62}$ This possibly affected the pictorial renewal that occurred in the scriptorium of Alcobaça during this period. The filigree pen work will confirms our hypothesis that this scriptorium was influenced by the colour initials with filigree of these university manuscripts.

${ }^{58}$ Boespflug, Les Théophanies bibliques.

${ }^{59}$ Pecia was a system of copying manuscripts, used in the thirteenth and fourteenth centuries, in which university-approved exemplars were divided into sections of three or more folios and were hired out by stationers to scribes.

${ }^{60}$ On the origin of these two manuscripts in the scriptorium of Alcobaça: Peixeiro, Missais iluminados; Peixeiro, "A iluminura

AQ3 em Alcobaça"; Peixeiro, “Um Missal cisterciense iluminado (Alc. 26)"; Peixeiro, "As cores das imagens"; Barreira, "Um Missal alcobacense"; Barreira, "Le Compendium theologicae veritatis", 105 - 129; and, Barreira, "Contributos para o estudo do Compendium Theologicae", 41 - 61.

${ }^{61}$ Bibles: Alc. 458 (1225-1230); Alc. 205 (1235-1245) and Alc. 455 (1235-1240) according to Patricia Stirnemann in Stirnemann, "Manuscritos Bíblicos", 44-6.

${ }^{62}$ University manuscripts copied by pecia: Alc. 417, Sententiarum Liber de Peter Lombard (1260 and 1270); the already mentioned (footnote no. 6) Alc. 261, Commentum in librum quartum Sententiarum Petri Lombardi. From the last quarter of the thirteenth-century/beginning of the fourteenth: Alc. 265, Commentarium of Sententiarum Librum III, by Thomas Aquinas, Alc. 40 Legenda Aurea, by Jacques de Voragine. From the beginning of the fourteenth century Alc. 264, Expositio in Evangelium Matthei by Nicolaus Gorranus. In this group of manuscripts we can include five more manuscripts: although they do not exhibit pecia marks, they all have characteristics of university manuscripts and all are of French origin (Alc. 269, Alc. 268, Alc. 266, Alc. 262, Alc. 383 and Alc. 439). 


\section{Filigree}

With respect to the filigreed coloured initials of this breviary, their importance is significant for the identity of the Alcobaça scriptorium, as the studies carried out by Patricia Stirnemann have demonstrated. ${ }^{63}$

We surveyed the Alcobaça manuscripts, in which the filigreed coloured initials are similar to the initials of the primitive core of this manuscript: the closest manuscripts are Alc. 26 and Alc. 376 (but also Alc. 210) as well as Alc. 52, a Doctrinale by Alexandre Villedieu and the Alc. 66 Breviary. In all of the aforementioned manuscripts, the filigree of the coloured initial is filled in using spiral motifs and curlicues on the exterior. ${ }^{64}$ The differences lie in the thickness of the lines, which are thicker in Alc. 54, as well as the colour: sometimes the flourished initials are sepia-coloured, whereas on other manuscripts they are always blue or red. We should note that the importance of the flourish does not put to rest the question of the manuscript's origin, but it is an essential aspect of dating. We may state that there is a change in the filigree concerning the manuscripts from the Alcobaça scriptorium during the end of the thirteenth century and the first quarter of the thirteenth century. It is very clear when we observe the colour initials from the manuscripts of the first quarter of the thirteenth century, as these are different: for example, the breviaries Alc. 30 and Alc. 10 have colour initials without filigree. A testament to the evolution of the coloured initial with filigree are the manuscripts Alc. 45, dated to 1289, and Alc. 28 and Alc. 8, dated to the end of the thirteenth century and the first years of the fourteenth century, respectively; these three manuscripts testify to a period of transition, a formal evolution of the scriptorium, which we propose was caused by the arrival of French university manuscripts at the abbey.

With respect to the additions to this manuscript, in the first, which goes from fol. 310r to fol. $327 \mathrm{v}$, at the start of the twenty-eighth quire, there is a change to a specific type of flourished initial and colour palette: purple appears and the flourish now looks more like a whip. In most cases, and in this precise one, it is more complex (for example, on fol. $317 \mathrm{v}$ the hymn of St Martin has a red initial with an exuberant purple flourish that forms flowers and curled motifs: Figure 5). As we will discuss in the next section, this purple is an orchil colour, which has been found in important ninth-century illuminated manuscripts such as the Book of Kells, ${ }^{65}$ falling into disuse during the Middle Ages (twelfth to thirteenth centuries at least). We can note the same type of colour initial with a curly flourish on manuscripts such as Alc. 7, a Gradual ${ }^{66}$ - it should be noted that this was from the fifteenth century, and in Alc. 73 , Alc. 453 , Alc. 451 and Alc. $278 ;^{67}$ this was a motif that was explored by the scriptorium during the fifteenth century.

On fol. 328r to fol. 340v we find the second addition, which coincides with the initial of the other quire, the thirtieth - its initials are distinct from the previous addition, as is its letter type. The flourish disappeared and the initials are simplified; they became similar to the coloured initials that punctuate the rubrics of the manuscripts Alc. 63 and Alc. 218,

\footnotetext{
63"Ornament is even more important than miniatures as a tool for dating and placing manuscripts because of the pyramid of craftsmen. ( ... ) Monasteries with large homemade libraries operate largely in a vacuum and tend to create ingrown families of books with similar script, ornament and display script that we can structure in time." In Stirnemann, "Dating, Placing and Illumination", 155-6. See also Stirnemann, "Fils de la Vierge", 58-73.

${ }^{64}$ See: Alc. 54 http://purl.pt/25620; Alc. 26 http://purl.pt/24863; Alc. 66 http://purl.pt/26147.

AQ4 ${ }^{65}$ Doherty et al., "The Book of Kells", 330-6.

${ }^{66}$ This Gradual is incorrectly dated from the fourteenth century; see Anselmo, Inventário dos códices alcobacenses, 16-17.

${ }^{67}$ See: Alc. 54 http://purl.pt/25620; Alc. 7 http://purl.pt/24805; Alc. 63 http://purl.pt/25142.
} 

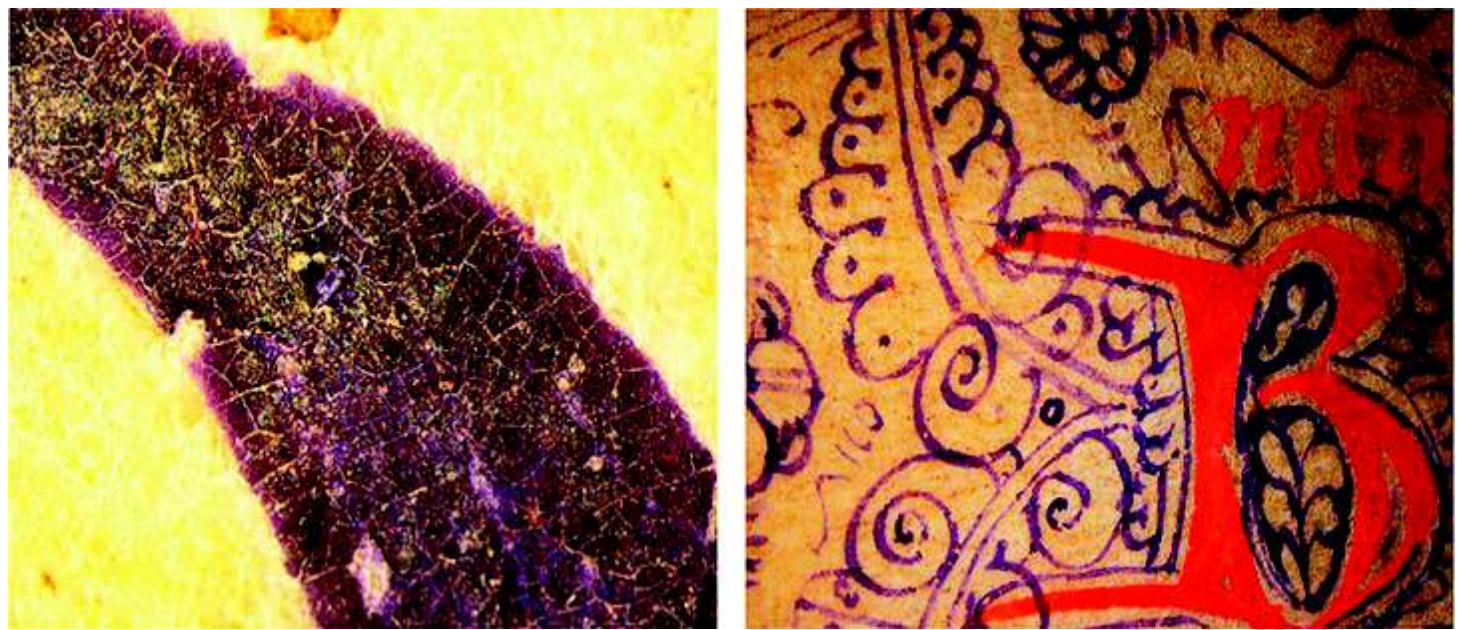

Figure 5.

two manuscripts made in the abbey's scriptorium. ${ }^{68}$ The coloured initials grew simpler in the Alcobaça scriptorium towards the end of the fifteenth century.

\section{Dating overview}

In summary, based on a detailed analysis of the construction of the illumination, in particular the filigree ornament used for the initials, the winter Breviary should be dated to the first years of the fourteenth century, that is, between 1300 and 1317 (original corpus), according with the offices in the Sanctoral, with two additions in the second half of the fifteenth century. With respect to the dating of the core manuscript, a study of the historiated initials provided us with a few leads: the proximity of the design, the motifs used to adorn the inside of the initials, and the characteristics of the respective branches connect this manuscript to two others: Missal Alc. 26, which dates to between 1318 and 1324; and Alc. 376, the Compendium Theologicae Veritatis, dated to 1332, two manuscripts we have already studied. We also refer to Alc. 52, a Doctrinale attributed to the Inventário, ${ }^{69}$ which is dated to some time during the first quarter of the fourteenth century.

With respect to the pen-flourished initials, we have noted their importance to the "dating and placing"70 process for manuscripts, especially when we have a set of manuscripts from a monastic scriptorium such as Alcobaça, and we have examples of the characteristics of the production before and after. Thus, the similarity of the penflourished initials in this breviary and those in other Alcobaça manuscripts further emphasises the chronological connections.

With respect to the additions (the first addition is of the same hand (fol. 310 to fol. 325), but the the second addition is by several hands), both date to the fifteenth century: with respect to the flourishes in the coloured initials, both display either initials with a whip flourish (first addition) or simpler and more stripped-down colour initials (second addition). Chronologically, they are dated close to a set of manuscripts that were copied in Alcobaça 1440-1450, such as the Gradual Alc. 7, the Regra de S. Bento Alc. 73

\footnotetext{
${ }^{68}$ About the Alc. 63 see Barreira, "Questões em torno dos Ordinários do Oficio."

${ }^{69}$ Anselmo, Inventário dos codices alcobacenses, 50-1.

${ }^{70}$ Stirnemann, "Dating, Placing and Illumination."
} 


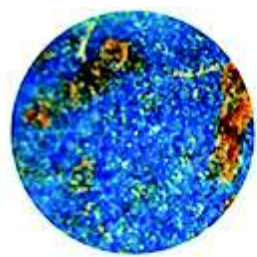

Azurite

$2 \mathrm{CuCO}_{3} \cdot \mathrm{Cu}(\mathrm{OH})_{2}$

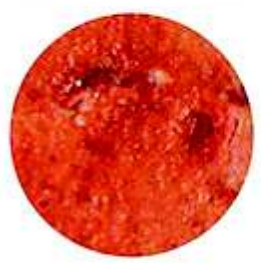

Brazilwood lake

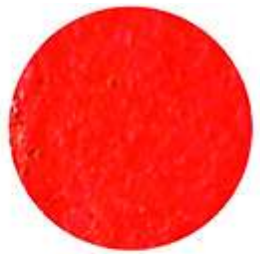

Vermillion $\mathrm{HgS}$

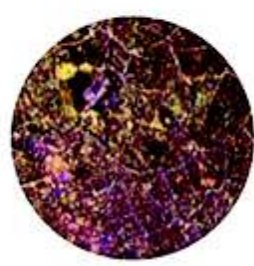

Purple

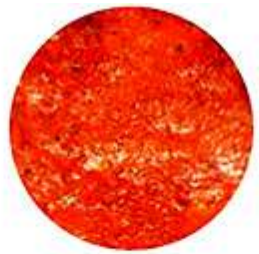

Minium $\mathrm{Pb}_{3} \mathrm{O}_{4}$

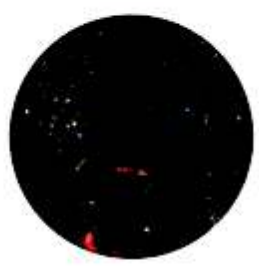

Carbon black

C

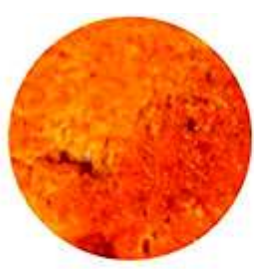

Yellow ochre $\mathrm{FeO}(\mathrm{OH})$

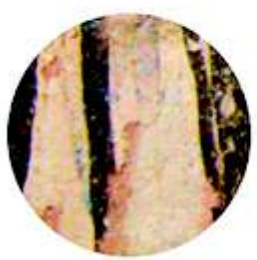

Lead white $2 \mathrm{PbCO}_{3} \cdot \mathrm{Pb}(\mathrm{OH})_{2}$

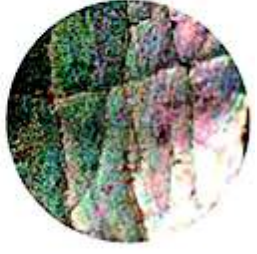

Silver

Ag

Figure 6. Molecular palette of the winter-season breviary (Alc. 54): azurite, vermilion, minium, yellow ochre, brazilwood lake pigment, orcein purple, carbon black, lead white, silver. For the molecular structures of the two dyes see Melo et al., "Spectroscopic Study of Brazilwood Paints" and "Organic Dyes in Illuminated Manuscripts".

(approximately 1450), the Vita Christi Alc. 451 to 453 (1440-1450), in the Livro dos Usos Alc. 278 (1444) and Livro das Colacções dos Santos Padres from Cassiano, Alc. 386 (14311446). With regard to the colour initials, they exhibit a curious characteristic: on the inside there are two small parallel lines, one above and one below, which characterise the manuscript Costumes, definições, visitações e estatutos da Ordem de Cister, Alc. 218 (1439-1440) but also Alc. 63, an Ordinário do Oficio Divino (1483). This implies that this type of initial was used for a long period of time in the monastery's scriptorium and that the two additions should be dated sometime in the mid fifteenth century, around 1450-1483.

\section{What the materials tell us about colour and dating}

When compared with illuminations from the twelfth and thirteenth centuries produced in the Alcobaça scriptorium, the materials used in the fourteenth-century winter Breviary allow us to draw the following conclusions (Figure 6).

(1) The colourants are different from the molecular palette used in the twelfth and thirteenth centuries, as are the artistic forms (Figure 6); thus, in the breviary original corpus, we found that the lapis lazuli blue and the dark red lac dye are substituted with azurite blue and pink brazilwood lake pigment. ${ }^{71}$ The latter is applied in the decorated and historiated initials, and further on to the vestment of Saint Stephen, which makes this figure stand out (fol. 198r) (Figure 7).

The colour green is absent. We find this rather significant, as it was one of the three principal colours of the twelfth- and thirteenth-century palette in the Alcobaça scriptorium. $^{72}$ XRF analysis confirmed the application of silver at the base of the initials on

\footnotetext{
${ }^{71}$ The molecular origin of the colour was characterised by microspectrofluorimetry as described in a forthcoming publication: Melo et al., "Organic dyes in illuminated manuscripts."

${ }^{72}$ Melo, Castro and Miranda, "Colour: between Beauty and Meaning", 182-4.
} 

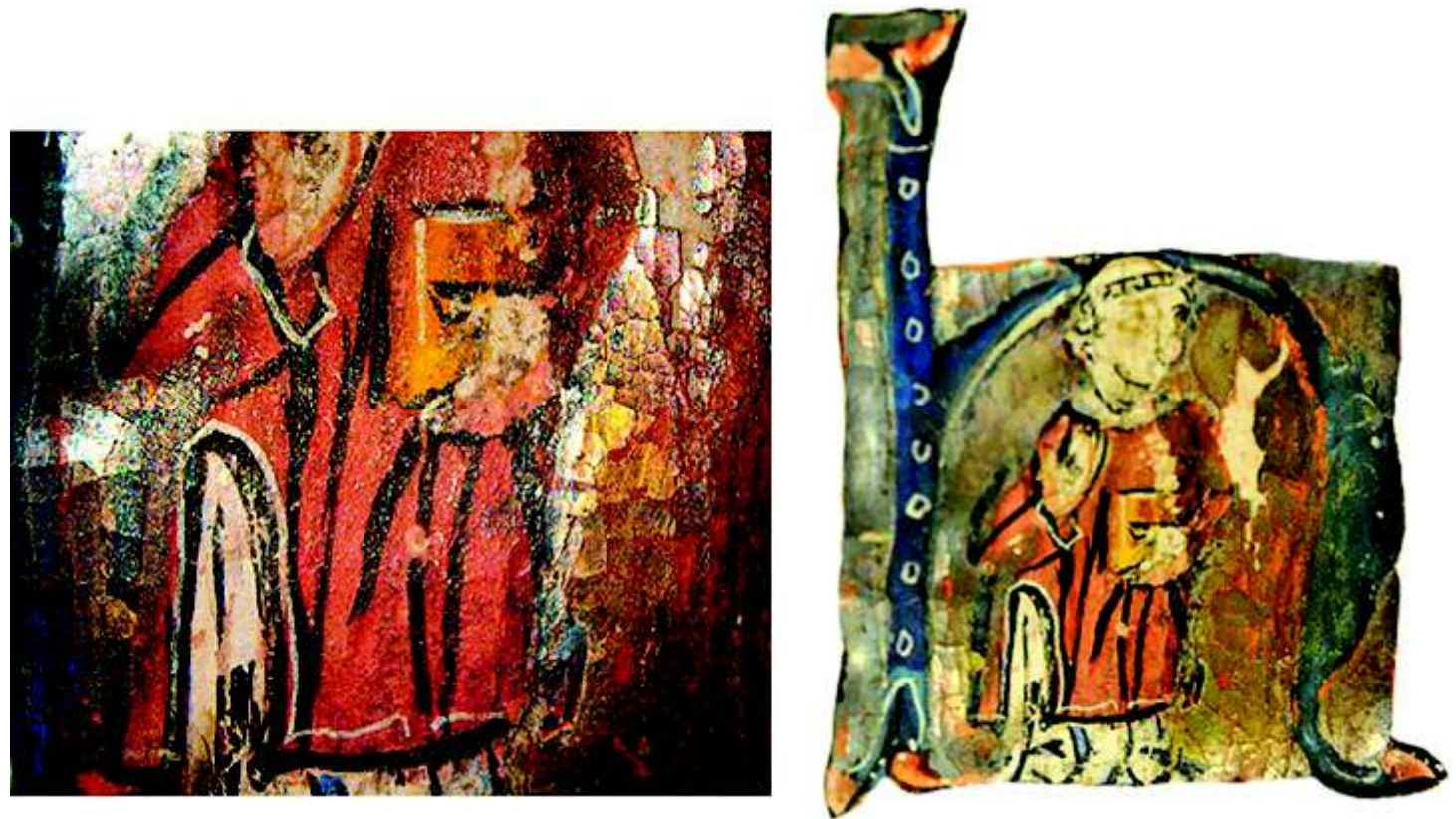

Figure 7. Colour application in the historiated initial on fol. 198 (right), Alc. 54 (fourteenth century): detail of the brazilwood lake pigment in the clothes of Saint Stephen (left).

fols. 69, 92, 198 and 219 (Figure 3), a metal colour that is not found in early manuscripts of the abbey. Note that the silver colour has been altered significantly - once brilliant, it has blackened due to oxidation, in such a way that it is impossible to recognise the colour with the naked eye - but we have been able to infer its presence by its degradation process and confirm it by detecting the silver element. In addition to lost shine and its darkening, this colour is also losing its adhesion, laying bare a preparation of red that would have been obtained by mixing vermillion and gypsum (Figure 8 ). This preparation indicates that silver metal leaf was applied, and its preparation is described in treatises and recipes from the fourteenth and fifteenth centuries, notably the "Bolognese manuscript", "Jehan le Begue", "Montpellier manuscript" and the "Göttingen Model Book". ${ }^{3}$

The yellow colour is achieved not by poisonous orpiment or an organic colourant such as saffron, but rather by using a well-defined yellow ochre, applied on the body of the stork (fol. 92r), in the book Saint Stephen holds in his hand (fol. 198r) as well as on ornamental details within the initials of fols. 92r and 219r (Figures 2 and 8). This pigment's colour comes from iron oxides (goethite and hematite) in an aluminium-silicate matrix (kaolin, quartz and calcium carbonate) (Figure 9).

(2) Continuity with the twelfth and thirteenth centuries is evidenced by the use of vermillion red ( $\mathrm{HgS})$ and two lead pigments, minium $\left(\mathrm{Pb}_{3} \mathrm{O}_{4}\right)$ and lead white (Figures 10 and 11). The connection with previous colour preparation/application techniques is also evident in the proteinaceous binding medium. In colours such as azurite blue, lead white and carbon black, the percentage of protein is so small it becomes invisible in terms of the technique used for its characterisation, microFTIR (Figures 12 and 13); however, in the remaining colours, we find a protein or mix of proteins (which for example, could be parchment glue and egg white).

\footnotetext{
${ }^{73}$ Merrifield, Medieval and Renaissance Treatises, 166, 238 and 470; Clarke, Mediaeval Painters' Materials and Techniques, 132; Lehmann-Haupt, The Gottingen Model Book, 41.
} 

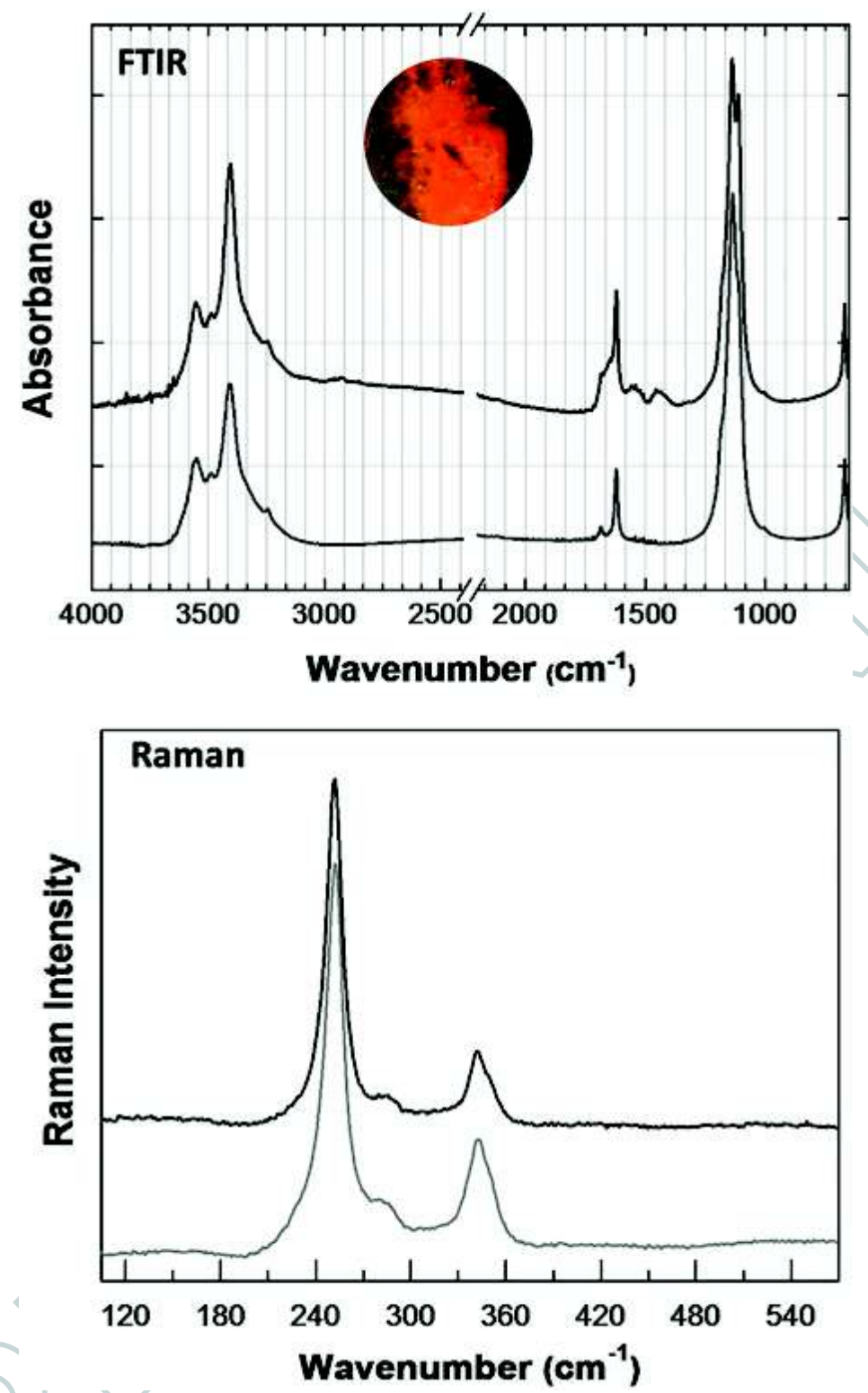

Figure 8. Spectral characterization of silver colour in Alc. 54, initial on fol. 92 (detail in the inset): infrared spectra of the red ground and of a reference for gypsum, black and grey lines, respectively; Raman spectra for the same.

This palette is somewhat different from the manuscripts from the first period of the monastery's existence. What is the reason for this difference? We think that a change began in the last quarter of the thirteenth century, when the first "university" manuscripts would have begun arriving at the abbey's library; these were all French in origin (we have counted a total of fourteen, but future research might add new ones to the growing list). In one of these manuscripts, Alc. 261 on fol. $269 \mathrm{r},{ }^{74}$ we found at the end of the index, written in red dye: "Iste liber est fr[at]ris Pet [ri] de Hyspania monachi Clar[evallis] studentis apud sanctum Ber[nardum] Par[isius]..."75 Thus, there

\footnotetext{
${ }^{74}$ See Pereira, "A Pecia em manuscritos universitários", 262-5; Cepeda, "A produção universitária e a lluminura em Portugal", 282-3; Nascimento, "O livro de teologia", 251; Obert- Piketty, "Les lectures et les œuvres".

${ }^{75} \mathrm{On}$ this manuscript, see footnotes 6 and 41. On the academic peregrination, see Farelo, "Os estudantes e mestres portugueses", 191; Cocheril, "Les Cisterciens portugais et les études", 242.
} 

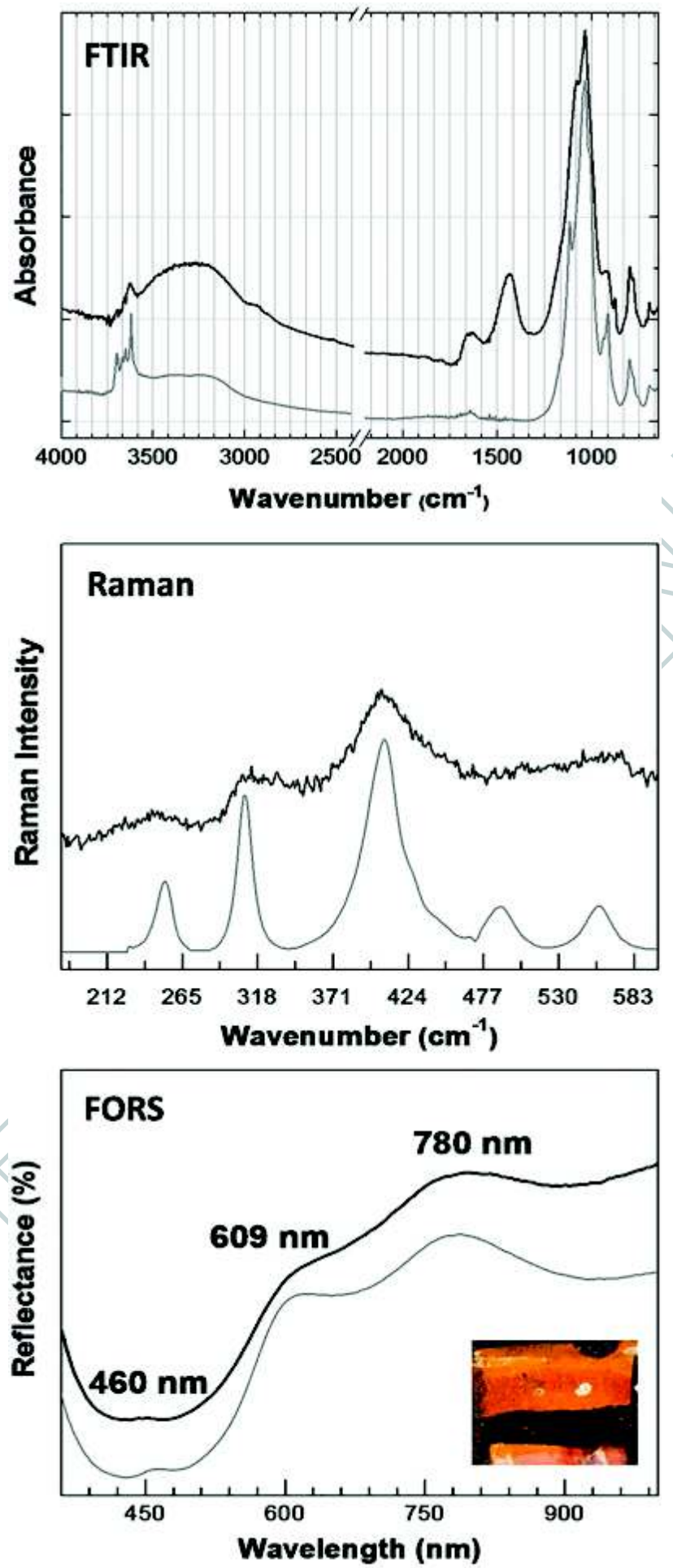

Figure 9. Spectral characterization of yellow ochre in Alc. 54, initial on fol. 219 (in the inset): infrared spectrum for yellow colour and for yellow iron oxide reference, black and grey lines, respectively; Raman spectra for ibid; reflectance spectra for the same.

is no doubt that this is a manuscript for university use that was acquired by a student Peter of Hyspania, monk of Clairvaux - at Saint Bernard College in Paris. It was common for students to bring manuscripts acquired during their stay in Paris back to their abbeys. The fact that this particular manuscript ended up in Alcobaça proves 

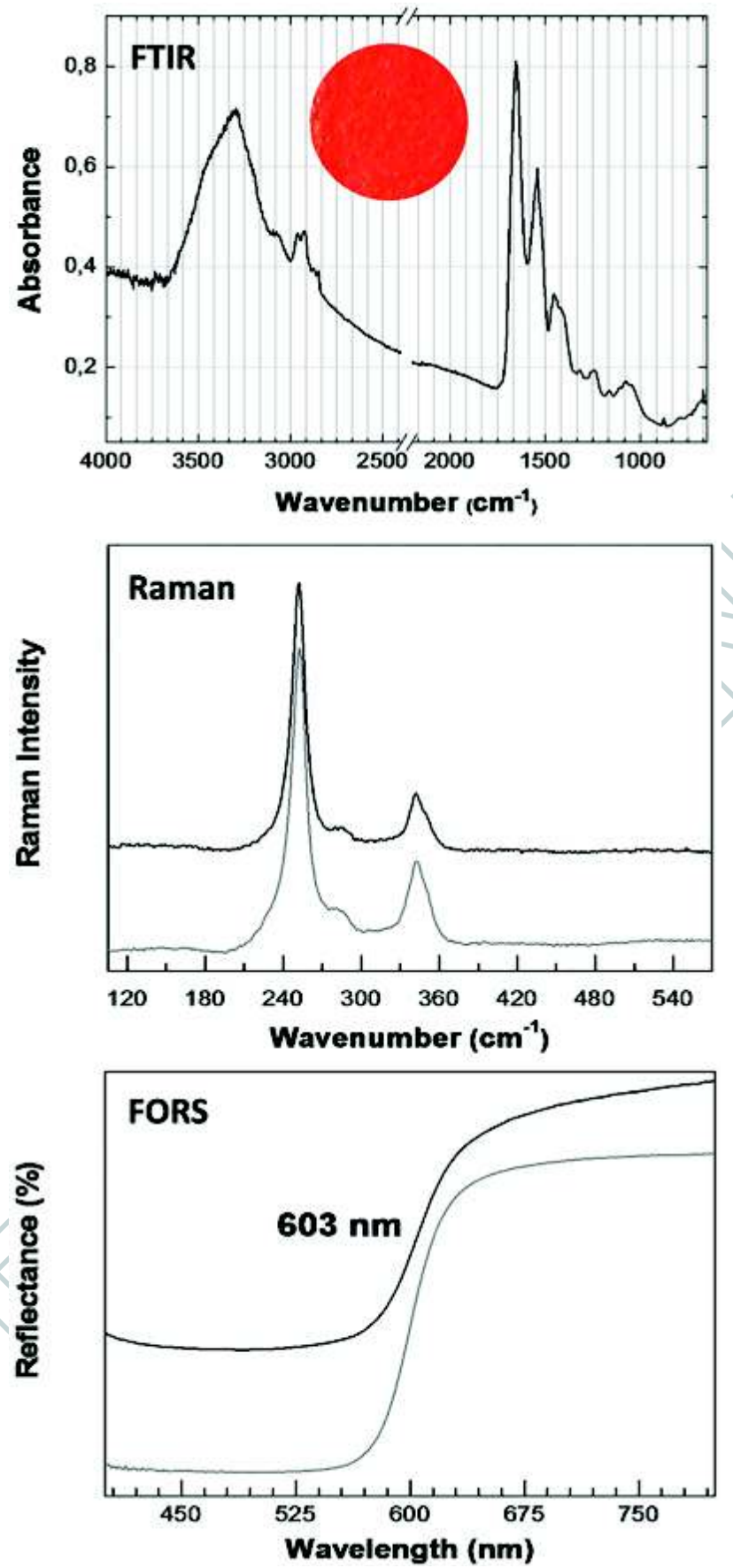

Figure 10. Spectral characterization of vermilion in Alc. 54, red initial on fol. 22 (detail in the inset): infrared spectrum of the red colour; Raman spectra of the red colour and of a reference for vermilion: black and grey lines, respectively; reflectance spectra for the same.

that there was an interchange between Paris University, Clairvaux and Alcobaça, as Caroline Obbert Piketty has previously noted. ${ }^{76}$

What impact did this new information have on the scriptorium? We propose that the presence of these manuscripts influenced the change of the palette and the filigree. We will further pursue this line of work, enlarging the set of manuscripts studied, to demonstrate that these French manuscripts influenced production at the scriptorium 

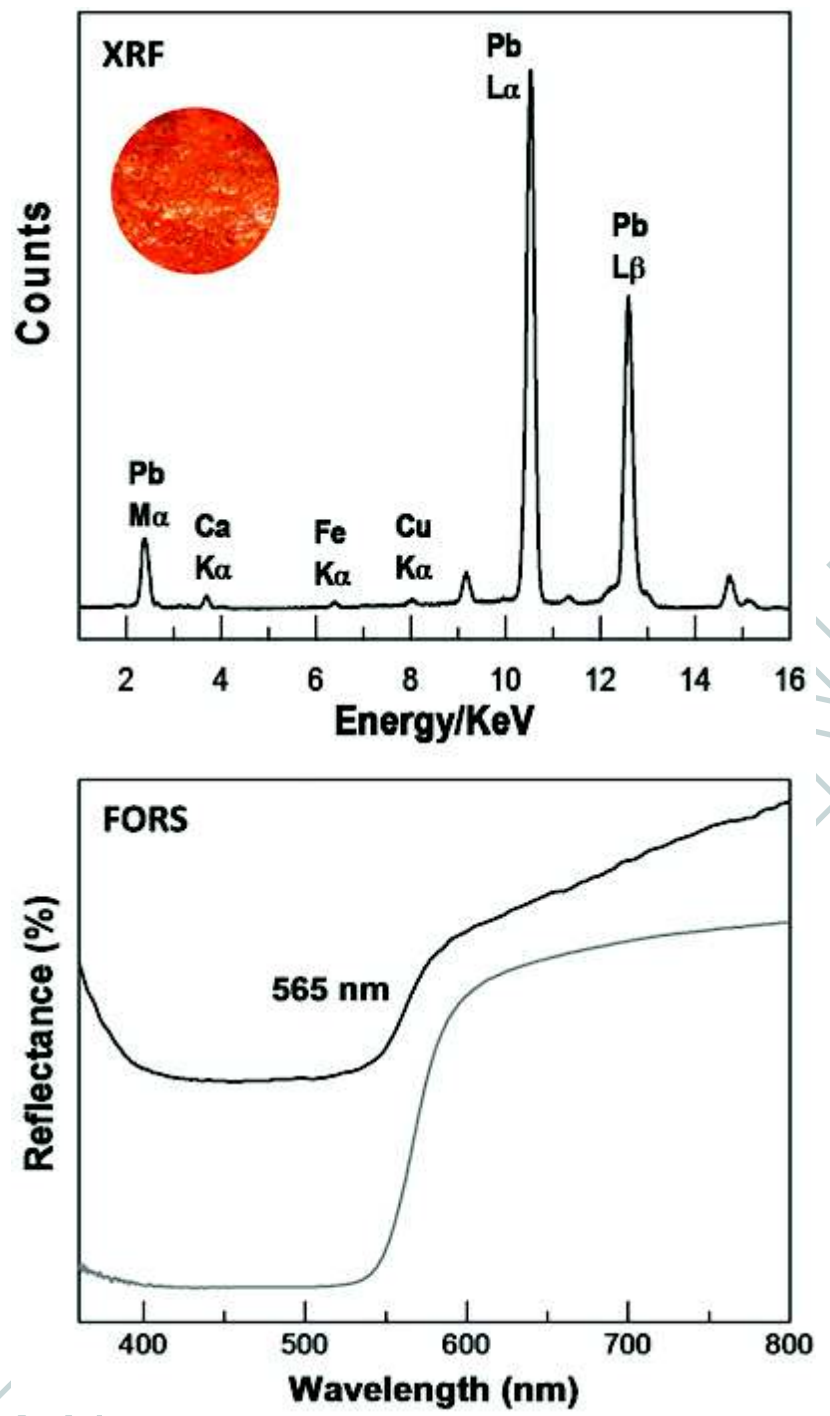

Figure 11. Spectral characterization of minium in Alc. 54, fol. 92 (detail in the inset): XRF and FORS, reference spectrum grey line.

and also had an impact on the materials selected - the use of other pigments (ochre yellow, brazilwood lake pigment, azurite) demonstrates that the scriptorium was modern and up to date. This breviary in particular includes silver (detected for the first time) and contains no green, but Alc. 26 and Alc. 376 do. In other words, the green did not disappear from the Alcobaça palette in the first quarter of the fourteenth century, thus indicating continuity.

The evolution of the palette accompanied the evolution of the illuminated decoration, which, because of this French influence that stemmed from the presence of university manuscripts, caused the scriptorium to adapt to the influences received something which can be noted, for example, in the historiated initials which reflect French influence, but are "ruder" and more expressive. This is also seen in the first quarter of the fourteenth-century filigree ornament. With respect to the presence of silver, we ask ourselves: is it possible that through this circulation several manuscripts using silver would have reached Alcobaça? This may well be the case, but we have yet to find them. 

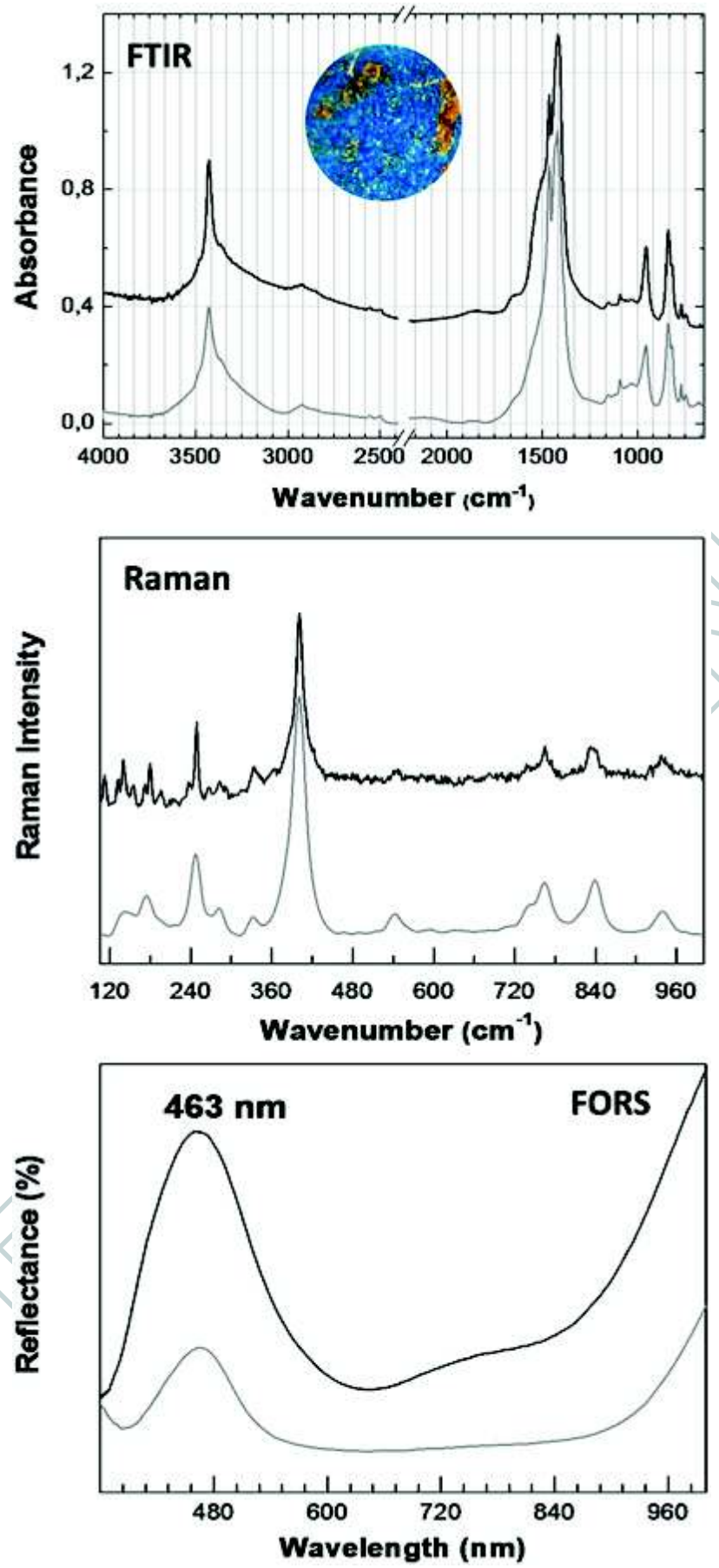

Figure 12. Spectral characterization of azurite in Alc. 54, blue initial on fol. 92 (detail in the inset): infrared spectra for blue colour and for azurite reference, black and grey lines, respectively; Raman spectra for ibid; reflectance spectra for the same.

\section{Colour palette overview}

Are the materials used as colourants, represented in Figure 6, in accordance with the dating proposed by art-historical analysis? Can the use of silver be characterised as an introduction of the fourteenth century in Alcobaça and/or in a French context?

These are questions we would like to be able to answer with a simple yes or no, but our current state of knowledge does not allow us to be as definitive as we would like. 

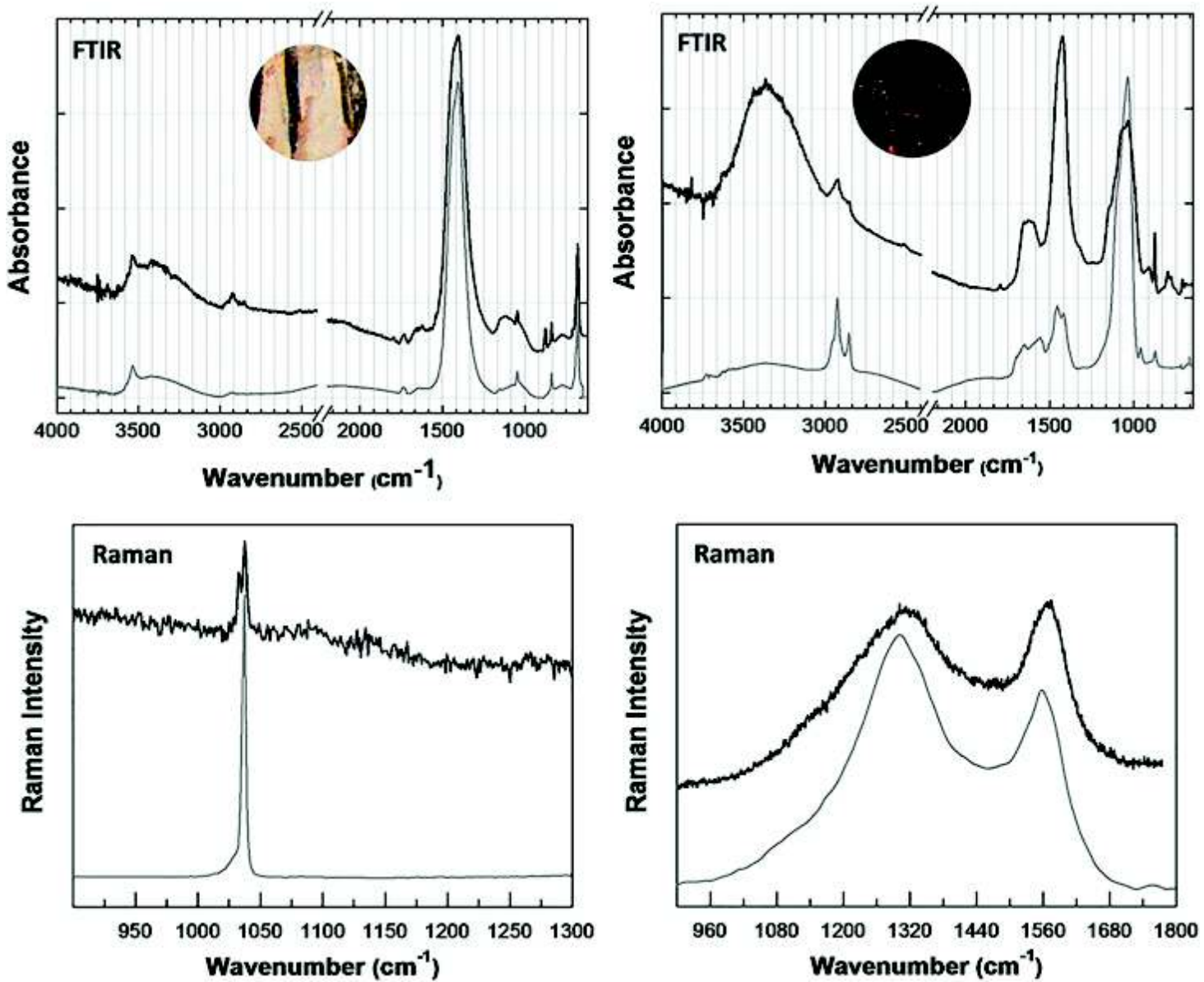

Figure 13. Spectral characterization of lead white and carbon black in Alc. 54, fol. 92 (detail in the inset): infrared spectrum of lead white and carbon black on the initial and a reference spectrum of lead white and carbon black: black and grey lines, respectively; Raman spectra for the same.

Previous systematic studies on book illumination produced in Portuguese monastic scriptoria and on Books of Hours in Portuguese collections provide us with a map and a chronology of the use of materials in the twelfth, thirteenth and fifteenth centuries, but this is not yet the case for the fourteenth. Nevertheless, we may argue that the colourants used point to our proposed date. Of particular note is the substitution of brazilwood carmine with orcein purple in the fifteenth-century addition. ${ }^{77}$ Recent evidence $^{78}$ indicates that this dye was indeed present in antiquity and the Early Middle Ages, but during the high Middle Ages, in Europe, it fell into disuse (Figure 5). Franco Brunello proposes that an Italian merchant rediscovered it in the Levant and was responsible for its reintroduction in Europe ca $1300 .^{79}$

${ }^{77}$ Orcein purple is a dye obtained from lichens, as described in Cardon, Natural Dyes: Sources, Tradition, Technology and Science, 485-514. The use of orcein purple is not explored in this study, as details of the dye characterisation will be presented in a forthcoming publication. We know that it was used in a broad time-frame, starting with the Book of Kells, into the sixteenth-century Fernão Vaz Dourado Atlases and until the nineteenth-century Livros das Irmandades.

AQ5 See Doherty et al., "The Book of Kells"; Melo et al., "Fernão Vaz Dourado's Colours": we know now that the purple colour used in these atlases is orcein-based.

${ }^{78}$ Melo et al., "Organic dyes in illuminated manuscripts."

${ }^{79}$ Brunello, "L'arte della tintura", 136. 


\section{Conclusions}

After analysing the colour materials used to illuminate the winter Breviary, it is noteworthy that we found a protein-based binding medium in both the main body of the manuscript, dated to the first half of the fourteenth century, as well as in the two additions from the second half of the fifteenth century. This discovery is relevant since in the production of a fifteenth-century Book of Hours that we have been analysing, the binder is mostly a natural gum such as gum arabic (polysaccharide) or a mix of a vegetable resin with a protein, ${ }^{80}$ and this practice of mixing binders is described in technical treatises from the fourteenth century such as the "Montpellier Manuscript". 81 This binding medium attests to a long-standing tradition of monastic production in the twelfth and thirteenth centuries in Portugal, where our studies have revealed the exclusive use of protein binders. ${ }^{82}$

Regarding the materials used in this manuscript, we see both a continuity, as is the case with the protein binding medium, and novelties that indicate the start of a transformation in relation to the materials used by the Alcobaça scriptorium between the end of the twelfth century and the first half of the next. This change contributed to the evolution of the technological context - documented through the existence of the same yellow ochre as found in the "Ajuda Songbook" (Cancioneiro da Ajuda) - but also the presence of those "university" manuscripts that originated in a book market and were notably connected to the university in Paris, which between the end of the thirteenth century and the start of the fourteenth began to enrich the library and influence the illuminations created by the scriptorium. This is reflected in the use of silver and brazilwood paints.

By bringing together art history and conservation sciences, ${ }^{83}$ we have highlighted the impact on the production of illuminated manuscripts caused by the "university" manuscripts' entrance into the world of the abbey. We do not know exactly when this change took place at the scriptorium, although this is something we might be able to pin down by analysing more manuscripts copied at Alcobaça especially toward the end of the thirteenth century, when some manuscripts demonstrate changes in the colour initials and filigree, and a formal transition of the filigree (see Alc. 45 dated from 1289, but also Alc. 28 and Alc. 8, dated to the turn of the fourteenth century): that is, between the arrival at the abbey of the first French university manuscripts and the first quarter of the fourteenth century.

In this paper we present the first study of the materials used in the production of fourteenth-century illuminations in a Portuguese monastic scriptorium - this analysis plus the "colourant chronology" proposed offer significant conclusions. ${ }^{84}$ Here, art history supports the construction of a corpus of knowledge for conservation sciences, allowing us to suggest a timeline for the materials used in this monastic scriptorium.

${ }^{80}$ Wieck, Time Sanctified; Lemos, Catálogo dos Livros de Horas, 99.

${ }^{81}$ Clarke, The Montpellier Liber diversarum arcium.

${ }^{82}$ Melo, Castro and Miranda, "Colour: Between Beauty and Meaning".

${ }^{83}$ Wouters, "Protecting Cultural Heritage".

${ }^{84}$ Concerning similar studies with interdisciplinary teams working together on illuminated manuscripts, see Claude Coupry, "D'une science à l'autre: Chimie et manuscrits médiévaux". This article discusses similar research that has been undertaken, and we observed that the fourteenth century had not received much attention. Similar research in art history and the conservation sciences has been undertaken concerning Books of Hours of the fifteenth century: see Lemos et al., "Regards croisés des historiens de l'art". 
In conclusion, this article is a first step in an interdisciplinary approach to mapping the identity of the Alcobaça Monastery scriptorium, which produced illuminated codices from the end of the twelfth century until at least the sixteenth century, in a place where tradition and modernity coexisted.

\section{Acknowledgements}

The work of art we studied is preserved at the Biblioteca Nacional and the research carried out has been made possible by the support and collaboration of the directors and staff. This study was funded by the Portuguese Science Foundation through a Post-doctoral Grant awarded to Catarina Fernandes Barreira [SFRH/BPD/70067/2010] and PhD grant awarded to Rita Araújo [SFRH/BD/ 52314/2013]. The authors would like to thank Rita Castro for her contribution with the identification of the dyes, Ana Lemos for all the advice and contributions and also Professor Saul António Gomes for his paleographic Reading (folios 229v and 340).

\section{Notes on contributors}

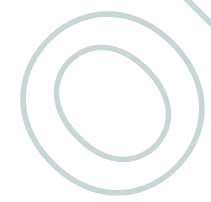

Catarina Fernandes Barreira has a PhD in Art Sciences (University of Lisbon, 2011). She is currently a post-doctorate fellow developing a research project on the Illuminated Manuscripts of the Monastery of Alcobaça between the fourteenth and the fifteenth centuries, funded by the Portuguese Foundation for Science and Technology (SFRH/BPD/70067/2010) and hosted at the Institute for Medieval Studies of the Nova University in Lisbon. She has participated as a researcher in two funded research projects, one on Hebrew illumination in Portugal (2012-15) funded by the Portuguese Foundation for Science and Technology, and another on Arts literacy (2012-13), funded by the Calouste Gulbenkian Foundation. Between 2000 and 2005 she was an Assistant Professor at the Escola Superior de Educação e Ciências Sociais (Leiria), where she became a Visiting Auxiliary Professor in 2009. Until 2015, she taught undergraduate courses and was a tutor of the MA in Art History. She is currently supervising PhD students in the Faculty for Social Sciences and Humanities of the Nova University in Lisbon. From January 2015 she has coordinated the research group "Images, Texts and Representations", with a body of 65 researchers, at the Institute 1065 for Medieval Studies of the above-mentioned Faculty.

Maria João Melo is Associate Professor at the Department of Conservation and Restoration of the Faculty of Sciences and Technology of the Nova University in Lisbon and a research scientist at REQUIMTE (Associated Laboratory for Sustainable Chemistry - Clean Processes and Technologies). Her current research subjects are focused on the study of colour of Portuguese medieval illuminations and the study of the molecules of colour in Art and Nature.

Rita Araújo holds a degree in Conservation and Restoration from the Faculdade de Ciências e Tecnologia of the Universidade NOVA de Lisboa (FCT-UNL). She has a master's degree in Conservation and Restoration at the same college, with the thesis "The Books of Hours (XV century) in the collection of the Mafra's National Palace: Study and Conservation". In 2013 she collaborated with the Department of Conservation and Restoration of FCT-UNL with a research scholarship, developing research alluding to the subject of her masters' dissertation. Currently, she is developing her doctoral thesis on the study and conservation of bindings of books of hours of the fifteenth century belonging to Portuguese collections in FCT-UNL, funded by the Portuguese Foundation for Science and Technology (SFRH/BD/52314/2013).

Maria da Conceição Lopes Casanova holds a $\mathrm{PhD}$ in Conservation and Restoration/Theory, History and Techniques. She is currently Auxiliary Researcher at the National Museum of Natural History and Science / Lisbon University and Invited Assistant Professor at the Faculty of Sciences and Technology of the Nova University in Lisbon. 


\section{Works cited}

Amos, Thomas L. The Fundo Alcobaça of the Biblioteca Nacional. Collegeville (Mn): Hill Monastic AQ6 Manuscript Library, 1989.

Andrieu, Michel. Le pontifical romain au moyen-age vol. I. Cittá del Vaticano: Biblioteca Apostolica Vaticana, 1938-1941.

Anselmo, António Joaquim. Inventário dos códices alcobacenses. Lisbon: Biblioteca Nacional, 1930.

Auberger, Jean-Baptiste. L'unanimité cistercienne primitive: mythe ou réalité. Achel: Administration de Cîteaux Commentarii Cistercienses, Editions Sine Parvulos, 1986.

Barata, Paulo. Os livros e o liberalismo: da livraria conventual à biblioteca pública: uma alteração de paradigma. Lisbon: Biblioteca Nacional, 2003.

1090 Barreira, Catarina Fernandes. "Manuscritos universitários para o estudo da Teologia na livraria do Mosteiro de Alcobaça." In Lusitânia Sacra: Mobilidades medievais. Centro de Estudos de

AQ7 História Religiosa da Universidade Católica, 2a série (forthcoming).

Barreira, Catarina Fernandes. "Contributos para o estudo do Compendium Theologicae veritatis no scriptorium de Sta. Maria de Alcobaça." In Actas do Congresso Internacional Mosteiros Cistercienses. Passado, presente, futuro, Tomo II, ed. José Albuquerque Carreiras, 41-61. Alcobaça: Edições Jorlis, 2013.

Barreira, Catarina Fernandes. "Le Compendium theologicae veritatis de l'abbaye d'Alcobaça." In Portuguese Studies on Medieval Illuminated Manuscripts, ed. Maria Adelaide Miranda and Alicia Miguelez, 105-29. Barcelona: Brepols, 2014.

Barreira, Catarina Fernandes. "A iluminura portuguesa no século XV e o Missal alcobacense 459." In O livro e as interações culturais judaico-cristãs em Portugal no final da idade média, ed. Luís

1100 Urbano Afonso Afonso and Paulo M. Pinto, 161-90. Lisbon: Cátedra de Estudos Sefarditas Alberto Benveniste, Fac. Letras Univ, Lisboa, 2014.

Barreira, Catarina Fernandes. "Ficha de catálogo do $\mathrm{n}^{\circ} 8$ - Ordinário do Ofício Divino da Ordem de Cister e Ars Manualis Alc. 62." In O livro e a iluminura judaica em Portugal no final da idade média, ed. Luís Urbano Afonso and Maria Adelaide Miranda, 125-126. Lisbon: Biblioteca Nacional de Portugal, 2015.

1105 Barreira, Catarina Fernandes. "Questões em torno dos Ordinários do Oficio Divino de Alcobaça." In Imagens e liturgia na idade média bens culturais da igreja, ed. Carla Varela Fernandes, 4, 111132. Lisbon: Secretariado Nacional para os Bens Culturais da Igreja, 2015.

Barreira, Catarina Fernandes. "Um Missal alcobacense dos inícios do séc. XIV (Alc. 26)." In Medieval Europe in Motion. The Circulation of Artists, Images, Patterns and Ideas from the Mediterranean to the Atlantic Coast, ed. D. Ciccarelli and M. A. Billotta. Palermo: Officina de Studi Medievali (forthcoming).

Barreira, Catarina Fernandes: "O martírio de Santo Estevão em três manuscritos iluminados da abadia cisterciense de Alcobaça." In Anuario de Estudios Medievales (forthcoming).

Benulic, Barbara. "Cistercian Legendarium (Alc. 421) from Alcobaça: The Problem of Ornamented

AQ8 Quire Signatures.” Zbornik za umetnostno zgodovino 43 (2007): 205-18.

Berman, Constance Hoffman. The Cistercian Evolution: The Invention of a Religious Order in Twelfth-century Europe. Philadelphia: University of Pennsylvania Press, 2000.

Boespflug, François. Les Théophanies bibliques dans l'art médiéval d'Occident et d'Orient. Genève: Librairie Droz, 2012.

Bondéelle-Souchier, Anne. Bibliothèques cisterciennes dans la France médiévale. Paris: CNRS, 1991.

Bondéelle-Souchier, Anne. "Trésor des moines. Les Chartreux, les Cisterciens et leurs livres." In Histoire de bibliothèques françaises. Les bibliothèques médiévales du VI siècle à 1530, ed. A. Vernet, 91-2. Paris: Editions du Cercle de la librairie, 2008.

Bragança, Joaquim Oliveira. Missal de Mateus. Lisbon: Fundação Calouste Gulbenkian, 1975.

Bragança, Joaquim Oliveira. "Pontifical de Braga do séc. XII: Porto, Biblioteca Municipal ms. 1134." Didaskalia VII (1977): 332.

Bragança, Joaquim Oliveira. Liturgia e espiritualidade na idade média. Lisbon: Universidade Católica Editora, 2007.

Brunello, Franco. L'Arte della tintura nella storia dell'umanità. Vicenza: Neri Pozza, 1968. 
Brunner, Birgit. "Colour in religion." In Colours in Culture and Science, proceedings of the Interdisciplinary Symposium in Hamburg, Oct. 12-15, 2010. Nuncius Hamburgensis Beiträge zur Geschichte der Naturwissenschaften, Band 22, ed. Gudrun Wolfschmidt. Hamburg: Tredition, 2011. ISBN: 9783842494688.

Canivez, Joseph. Statuta Capitulorum Generalium Ordinis Cisterciensis: ab anno 1116 ad annum 1786. Vol. 1. Louvain: Bibliothèque de la revue d'histoire ecclésiastique. Bureaux de la Revue, 1933.

Cardon, Dominique. Natural Dyes: Sources, Tradition, Technology and Science. London: Archetype Publications, 2007.

Carruthers, Mary. The Book of Memory. A Study of Memory in Medieval Culture. Cambridge: University Press, 2008.

Castro, Rita, Maria J. Melo and Adelaide Miranda. "The Secrets Behind the Colour of The Book of Birds.” In Portuguese Studies on Medieval Illuminated Manuscripts, ed. Maria Adelaide Miranda and Alicia Miguélez, 31-56. Barcelona: Brepols, 2014.

Cepeda, Isabel Vilares. “A produção universitária e a Iluminura em Portugal nos secs XIII a XV.” In A iluminura em Portugal. Identidades e influências (do séc. X ao XVI), ed. Adelaide Miranda and Aires Nascimento. Lisbon: Biblioteca Nacional de Portugal, 1999.

Cepeda, Isabel V., and Teresa D. Ferreira. Inventário dos códices iluminados até 1500. Vol. 1: Distrito de Lisboa. Lisbon: Secretaria de Estado da Cultura, 1994.

Cepeda, Isabel V., and Teresa D. Ferreira. Inventário dos códices iluminados até 1500. Vol. 2: Distritos de Aveiro, Beja, Braga, Bragança, Coimbra, Évora, Leiria, Portalegre, Porto, Setúbal, Viana do Castelo e Viseu. Lisbon: Secretaria de Estado da Cultura, 2001.

Clarke, Mark. Mediaeval Painters' Materials and Techniques: The Montpellier Liber diversarum arcium. London: Archetype Publications, 2011.

Cocheril, Maur. "Les Cisterciens portugais et les études. Etat de la question.” In Los Monges y los estúdios. 4a Semana de Estudios Monásticos. Poblet: Abadía de Poblet, 1963.

Coupry, Claude. "D’une science à l’autre: Chimie et manuscrits médiévaux. Étapes d’une évolution." In Bulletin du centre d'études médiévales d'Auxerre |BUCEMA [En ligne], mis en

1150 ligne le 08 septembre 2006, http://cem.revues.org/462 (accessed 10/11/2015). doi:10.4000/ cem.462.

Doherty B., F. Gabrieli, C. Clementi, D. Cardon, A. Sgamellotti, B. Brunetti and C. Miliani. "Surface enhanced Raman spectroscopic investigation of orchil dyed wool from Roccella tinctoria and Lasallia pustulata." Journal of Raman Spectroscopy 45 (2014): 723-9. doi:10.1002/jrs.4543.

Falmagne, Thomas. "Le réseau des bibliothèques cisterciennes." In Unanimité et diversité cisterciennes. Filiations - Réseaux - Relectures du XII" au XVII' siècle, 195-222. Saint-Étienne: Publications de l'Université de Saint-Étienne, 2000.

Falmagne, Thomas. Les Cisterciens et leurs bibliothèques. Troyes: Mediathéque du Grand Troyes, 2012.

Farelo, Mário. "Os estudantes e mestres portugueses nas escolas de Paris durante o período medievo (sécs. XII-XV): elementos de história cultural, eclesiástica e económica para o seu estudo."

1160 Lusitânia Sacra 2a série 13-14 (2001-2002): 161-96.

Garnier, François. Le langage de l'image au Moyen Age. Signification et symbolique. Paris : Editions Le Léopard d'Or, 1982.

Giles, J.A. The Complete Works of Venerable Bede. Vol. X Commentaries on the Scriptures. London, 1844.

Gomes, Saul. "Revisitação a um velho tema: a fundação do Mosteiro de Alcobaça in Cister. Espaços, Territórios, Paisagens.” Actas do Colóquio Internacional. Lisbon: IPPAR, 2000. Média. Aspectos globais e particulares." In Actas do IX Centenário do Nascimento de São Bernardo. Encontros de Alcobaçaça e Simpósio de Lisboa, 257-303. Braga: Universidade Católica Portuguesa, 1991.

Herder, Michelle M. "Liturgy and the Spiritual Experience of Religious Women at Santa Maria de Vallbona." Catalonia in Viator 40, no. 2 (2009): 171-96. 
Hunt, Elizabeth Moore. Illuminating the Borders of Northern French and Flemish Manuscripts, 1270-1310. London: Routledge, 2007.

Jamroziak, Emilia. The Cistercian Order in Medieval Europe 1090-1500. London: Routledge, 2013. Lebigue, Jean-Baptiste. Initiation aux manuscrits liturgiques. École thematique. Ateliers du Cycle thematique de l'IRHT de l'annee 2003-2004, dirige par Oliver Legendre et Jean-Baptiste, 2007, https://cel.archives-ouvertes.fr/cel-00194063/document (accessed 10/11/2015).

Legendre, Olivier. "Some Tools for Dating and Localizing Manuscripts." The Journal of the Early Book Society for the Study of Manuscripts and Printing History 11 (2008): 181-196.

Lehmann-Haupt, Hellmut. The Gottingen Model Book: A facsimile edition and translations of a fifteenth-century illuminators' manual, with commentary, based in part on the studies of the late Dr. Edmund Will. Columbia: University of Missouri Press, 1972.

Lemos, Ana. Catálogo dos Livros de Horas do Palácio Nacional de Mafra. Lisbon: IEM-FCSH / Palácio Nacional de Mafra, 2012.

Lemos, Ana, Rita Araújo, Conceição Casanova, Maria J. Melo and Vânia S.F. Muralha. "Regards croisés des historiens de l'art et des chimistes sur deux livres d'Heures de la Bibliothèque nationale du Portugal, les mss IL15 et IL19.” In Portuguese Studies on Medieval Illuminated Manuscripts, ed. Maria Adelaide Miranda and Alicia Miguelez, 145-68. Barcelona: Brepols, 2014.

Leroquais, Victor. Les Bréviaires manuscrits des bibliothèques publiques de France. Vol. 1. Paris [s.n.], 1934.

Maitre, Claire. Le bréviaire cistercien Troyes, Bibliothèque Municipale, MS.2030. Fribourg: Academic Press, 2015.

Mas, Sílvia, Catarina Miguel, Maria J. Melo, João A. Lopes and Anna de Juan. "Screening and quantification of proteinaceous binders in medieval paints based on $\mu$-Fourier transform infrared spectroscopy and multivariate curve resolution alternating least squares." Chemometrics and

AQ9 Intelligent Laboratory Systems 134 (2014): 148-57. doi:10.1016/j.chemolab.2014.03.012.

Mattoso, José. Obras completas. Poderes invisíveis. O imaginário medieval. Lisboa: Círculo de Leitores, 2001.

Melo, Maria J., Adelaide Miranda, Catarina Miguel, Rita Castro, Ana Lemos, V. Solange, F.

1195 Muralha, João A. Lopes and António Pereira Gonçalves. "The Colour of Medieval Portuguese Illumination: An Interdisciplinary Approach.” Revista de História da Arte, FCSH-UNL, nº, série W (2011): 152-73.

Melo, Maria J., Márcia Vilarigues, Vânia S.F. Muralha and Rita Castro. “Fernão Vaz Dourado’s colours.” In Universal Atlas of Fernão Vaz Dourado. 1571, ed. M Miró, 168-86. Barcelona: M. Moleiro Editor, 2013.

1200 Melo, Maria J., and Maria Adelaide Miranda. "Secrets et découvertes en couleur dans les manuscrits enluminés." In Portuguese Studies on Medieval Illuminated Manuscripts, ed. Maria Adelaide Miranda and Alicia Miguelez, 1-29. Barcelona: Brepols, 2014.

Melo, Maria J., Rita Castro and Maria Adelaide Miranda. "Colour in Medieval Portuguese Manuscripts: Between Beauty and Meaning." In Science and Art: The Painting Surface, ed. Antonio Sgamellotti, Brunetto G. Brunetti and Constanza Miliani, 170-92. London: Royal

1205 Society of Chemistry, 2014. Marcelo Picollo. "A Spectroscopic Study of Brazilwood Paints in Medieval Books of Hours." Applied Spectroscopy 68, no. 4 (2014b): 434-44.

Melo, Maria J., Rita Araújo, Conceição Casanova, Vânia S.F. Muralha and Ana Lemos. "Segredos descobertas nos Livros de Horas: história, materiais e técnicas.” In Livros de Horas: o imaginário

1210 da devoção privada, ed. Delmira Custódio and Adelaide Miranda. Lisbon: IEM /FCSH and AQ10 Biblioteca Nacional de Portugal (forthcoming).

Melo, Maria J., Paula Nabais, Maria Guimarães, Rita Araújo, Rita Castro and Conceição Oliveira. "Organic Dyes in Illuminated Manuscripts: A Unique Cultural and Historic Record?" Philosophical Transactions A (submitted).

Melo, Maria J., Rita Araújo, Vânia S.F. Muralha and Ana Lemos. "O que nos dizem os materiais da cor sobre os livros de horas do Palácio Nacional de Mafra?” In Os Livros de Horas iluminados do 
Palácio Nacional de Mafra, ed. Ana Lemos, 103-13. Lisbon: Instituto de Estudos Medievais /

AQ11 Faculdade de Ciências Sociais e Humanas, 2013.

Merrifield, M.P. Medieval and Renaissance Treatises on the Arts of Painting. London: Dover Publications, 1999.

Miguel, Catarina, João A. Lopes, Mark Clarke and Maria João Melo. “Combining infrared spectroscopy with chemometric analysis for the characterization of proteinaceous binders in medieval paints." Chemometrics and Intelligent Laboratory Systems 119 (2012): 32-8. doi:10.1016/j.

AQ12 chemolab.2012.09.003.

Miguélez Cavero, Alicia. "El dedo índice como atributo regio de poder en la iconografía románica de la Península Ibérica." Imágenes de poder en la edad media. Estudios in memoriam del Prof. Dr. Fernando Galvan Freile, vol. II, 325-40. León: Publicaciones Universidad de León, 2011.

Miranda, Adelaide. "Iluminura românica em Santa Cruz de Coimbra e Santa Maria de Alcobaça subsídios para o estudo da iluminura em Portugal." PhD diss., Universidade NOVA de Lisboa, 1996.

Muralha, Vània S.F., Catarina Miguel and Maria J. Melo. "Micro-Raman Study of Medieval Cistercian 12-13 $3^{\text {th }}$ Century Manuscripts: Santa Maria de Alcobaça, Portugal." Journal of

Raman Spectroscopy 43 (2012): 1737-46. http://dx.doi.org/10.1002/jrs.4065.
AQ13 Murano, Giovanna. Opere diffuse per exemplar e pecia. Turnhout: Brepols, 2005.

Nascimento, Aires. "Em busca dos códices alcobacenses perdidos." Didaskalia IX (1979): 279-88.

Nascimento, Aires A., and António Diogo. Encadernação portuguesa medieval. Alcobaça. Lisbon: Imprensa Nacional Casa da Moeda, 1984.

1235 Nascimento, Aires do Nascimento. "Concentração, dispersão e dependência na circulação de manuscritos nos séculos XII e XIII.” In Colóquio sobre a circulação de códices e escribas entre a Europa y La Peninsula entre los siglos VIII - XIII, 61-86. Santiago de Compostela: Universidade de Santigo de Compostela, 1988.

Nascimento, Aires A. Le scriptorium d'Alcobaça: Identité et corrélations. Lusitania Sacra. Lisbon: Centro de Estudos de História Religiosa - Universidade Católica Portuguesa, 1992.

1240 Nascimento, Aires A. "O livro de teologia: génese de uma estrutura e estruturação de uma ciência." Didaskalia XXV (1995): 235-55.

Nascimento, Aires A., and José F. Meirinhos. Catálogo dos Códices da Livraria de mão do Mosteiro de Santa Cruz de Coimbra na Biblioteca Municipal do Porto. Porto: Biblioteca Pública Municipal do Porto, 1997.

Nascimento, Aires A. "Percursos do livro na história da cultura portuguesa medieval." In Ler contra

1245 o tempo: Condições dos textos na cultura portuguesa. vol. 1, 269-317. Lisbon: Centro de Estudos Clássicos, 2012.

Nascimento, Aires A. “Tempos e livros medievos: os antigos codices de Lorvão." In Ler contra o tempo: Condições dos textos na cultura portuguesa. vol. 1, 389-410. Lisbon: Centro de Estudos Clássicos, 2012.

Obert-Piketty, Caroline. "Les lectures et les œuvres des pensionnaires du Collège Saint Bernard:

1250 jalons pour l'histoire intellectuelle de l'ordre de Cîteaux à la fin du Moyen Âge." Cîteaux 40 (1989): 245-91.

Palazzo, Éric. "Iconographie et liturgie dans les études médiévales aujourd’hui: un éclairage AQ14 méthodologique." Cahiers de civilisation médiévale 41 (161) (1998): 65-9.

AQ15 Palazzo, Éric. Liturgie et société au Moyen Age. Paris: Editions Aubier, 2000.

Pastoureau, Michel. "Le temps mis en couleurs : des couleurs liturgiques aux modes vestimentaires

1255 (XIIe-XIIIe siècles).” In Bibliothèque de l'école des Chartes, Tomo 157/1, 111-35. Paris: Librairie Droz, 1999.

Parodi, Gian Carlo. "Lapislazzuli. Cos'é. Dove si forma e dove si rinviene.” In Lapislazzuli, Magia del blu, ed. Maria Sframeli, Valentina Conticelli, Riccardo Gennaioli and Gian Carlo Parodi, 2132. Livorno: Sillabe, 2015.

Pereira, Isaías da Rosa. "A Pecia em manuscritos universitários. Estudo de três códices alcoba1260 censes dos séculos XIII e XIV.” Anais da Academia Portuguesa de História 22 (1973): $45-267$. 
Rêpas, Luís Miguel, and Catarina Fernandes Barreira. "Place and Liturgy in an Illuminated Ritual from Santa Maria de Alcobaça.” In Imagens e liturgia na idade média. Lisbon: Secretariado para os Bens Culturais da Igreja, 2016 (forthcoming).

Rocha, Pedro Romano. L'Office divin au moyen age dans l'eglise de Braga. Paris: Fundação Calouste AQ16 Gulbenkian, 1980.

1265 Sá, Fr. Francisco de. Index codicum Bibliothecae Alcobatiae, in quo non tantum codices recensentur, sed etiam quot tractatus, epistolas, \&c. singuli codices contineant, exponitur aliaque animadvertuntur notatu digna. Olisipone: ex Typographia Regia, 1775.

Santos, Maria José Azevedo. Vida e morte de um mosteiro cisterciense. S. Paulo de Almaziva. Lisbon: Edições Colibri, 1998.

Schmitt, Jean-Claude. La raison des gestes dans l'Occident médiévale. Paris: Gallimard, 1990.

Sousa, Luís Correia de. Sacra Pagina. Textos e Imagens das Bíblias portáteis do século XIII pertencentes às colecções portuguesas. Lisbon: Editora Paulus, 2015.

Stirnemann, Patricia. "Fils de la Vierge. L'initiale à filigranes parisiennes: 1140-1314." Revue d'Art 90 (1990): 58-73.

Stirnemann, Patricia. "Dating, Placing and Illumination." The Journal of the Early Book Society for the Study of Manuscripts and Printing History 11 (2008): 155-66.

Stirnemann, Patricia. "Manuscritos Bíblicos copiados no século XIII e conservados em Portugal.” In Sacra Pagina. Textos e imagens das Bíblias portáteis do século XIII pertencentes às colecções portuguesas, ed. Luís Correia de Sousa, 37-47. Lisbon: Editora Paulus, 2015.

Strolovitch, D. "O libro de como se fazen as cores das tintas todas (Transliteration)." In As Matérias

AQ17 da Imagem, ed. L.U. Afonso. Lisbon: Cátedra de Estudos Sefarditas «Alberto Benveniste», 2010.

1280 Viterbo, Sousa. Calígrafos e iluminadores portugueses: ensaio histórico-bibliográfico. Lisbon: O Instituto, 1916.

Waddell, Crysogonus. The Primitive Cistercian Breviary. Fribourg: Academic Press, 2007.

Waddell, Crysogonus. Twelfth-Century Statutes from the Cistercian General Chapter. Brecht:

AQ18 Cîteaux, Commentarii cistercienses, 2002.

Wieck, Roger S. Time Sanctified: The Book of Hours in Medieval Art and Life. London: Sotheby's Publications, 1988.

Wouters, Jan. "Protecting Cultural Heritage: Reflections on the Position of Science in Multidisciplinary." Chemistry International 30 (2008). Available at nzic.org.nz/CiNZ/articles/ Wouters_72_2.pdf and http://www.iupac.org/publications/ci/2008/3001/1_wouters.html.

Zaluska, Yolanta, and Marie-Françoise Damongeot. "Analyse liturgique du Lectionnaire de la messe (mss 177, fragment 1, et 154) et de l'Epistolier (ms 156) conservés aux Archives départementales de la Dordogne." In Manuscrits de Cadouin: Actes du colloque de Périgueux (20 et 21 juin 2013), 98-149. Dordogne: Archives départementale. Périgueux: Archives départementales de la Dordogne, 2015. 